Claremont Colleges

Scholarship@ Claremont

\title{
Parent Involvement in Contested Times: A Brief Analysis of the Effects of Anti-Immigrant Policies on Latinx Immigrant Parent Involvement
}

MARIA ISABEL MORALES

CLAREMONT GRADUATE

\section{Recommended Citation}

MORALES, MARIA ISABEL. (2019). Parent Involvement in Contested Times: A Brief Analysis of the Effects of Anti-Immigrant Policies on Latinx Immigrant Parent Involvement. CGU Theses \& Dissertations, 135. https://scholarship.claremont.edu/cgu_etd/135. doi: $10.5642 /$ cguetd/135 


\title{
Parent Involvement in Contested Times:
}

A Brief Analysis of the Effects of Anti-immigrant Policies on Latinx Immigrant Parent Involvement

\author{
by \\ Maria I. Morales
}

Claremont Graduate University

2019

(C) Copyright Maria I. Morales, 2019

All rights reserved. 


\title{
Approval of the Dissertation Committee
}

This dissertation has been duly read, reviewed, and critiqued by the Committee listed below, which hereby approves the manuscript of Maria I. Morales as fulfilling the scope and quality requirements for meriting the degree of $\mathrm{PhD}$ in Education with an emphasis on Teaching, Learning \& Culture.

Dr. Lucrecia Santibañez, Chair

Claremont Graduate University Associate University Professor School of Educational Studies

\author{
Dr. Melissa Rogers, Member \\ Claremont Graduate University \\ Assistant Professor of Political Science \\ School of Social Science, Policy \& Evaluation
}

Dr. Richard T. Rodriguez, Member University of California Riverside Associate Professor of Media and Cultural Studies and English College of Humanities, Arts, and Social Sciences 


\section{Abstract \\ Parent Involvement in Contested Times \\ by \\ Maria I. Morales \\ Claremont Graduate University: 2019}

How do perceived community and school cultural values affect Latinx immigrant parents' decisions to engage with their children's schools? What lessons might their experiences have for our understanding of parent involvement beyond the parameters of traditional models of parent involvement? Engaging parents as advocates for school success in the home is particularly important for English Language Learners (ELs). Tapping into the experiences of EL parents is a resource educators can use to increase parental involvement and, consequently, student academic achievement.

This qualitative case study grounded in Critical Inquiry and Cultural Historic Activity Theory examined the perceptions and experiences of 5 working-class Latino immigrant mothers whose children were enrolled in two elementary schools in southern California. Parents were purposively selected from two predominantly Latinx urban Elementary schools to participate in individual interviews and focus groups. This study addresses an urgent need to survey the current context of immigrant families and, because most research on the subject of parent involvement takes a subtractive or deficit approach that often devalues the experiences and perceptions of Latinx immigrant parents, it responds to a need for studies that approach the subject from an assetbased perspective that includes the voices of the parents themselves. Examining the narratives of the parents from their own perspectives, this study provides a platform from which parent voices can be heard and creates a space where the historical and current particulars of home and community practices, histories, and activities become as relevant as those of the dominant 
culture(s), thus creating equitable conditions where the social justice mission of education-which is to provide quality education for all-is more likely to be fulfilled.

Keywords: EL, parental involvement, Latino immigrant students, immigration policies 


\section{Dedication}

To mi familia, Diana, my PhinisheD sisters, and the many awesome individuals that contributed to the realization of this project: without your loving support and continuous encouragement, this dream would have never been realized. 


\section{Acknowledgments}

I would like to express deep gratitude and appreciation to my advisor Dr. Lucrecia Santibañez for her continuous support and encouragement. I would also like to thank my committee members Dr. Melissa Rogers and Dr. Richard T. Rodriguez for their time and dedication to this project.

Special thanks go out to my CLSA family for coming through for me and other Latinx students time and again. Ernie, Tony, Maria and Xochitl: words cannot express my gratitude! ¡Gracias por todo!

I am indebted to my sister Claudia and my brother Luis who, throughout the course of this Ph.D. adventure, have believed in me and supported my dreams showing me the true meaning of love. I love you both very much!

Agradezco de todo corazón a las mujeres que participaron en este estudio. Gracias por compartir sus experiencias y por abrir las puertas de sus corazones y hogares. Sus contribuciones fueron fundamentales para escribir una historia que debe ser compartida.

From the bottom of my heart, thank you all very much! 


\section{Preface}

\section{Rebeca's Story:}

The year is 1998, after attempts to make educating the children of undocumented immigrants illegal (Proposition 187) and to outlaw affirmative action in public employment and public education (proposition 209), Proposition 227 (also known as the "English for the Children” initiative) has just been passed outlawing bilingual education in California.

At this same time, after a 9-month odyssey across México, Rebeca, a Guatemalan indigenous woman, arrives in South Central Los Angeles to be reunited with her two children who had migrated to the U.S. one year earlier. Rebeca speaks K'iche' and some Spanish that she learned during her journey through Mexico. She is undocumented and determined to succeed.

One of the first things Rebeca does after settling in Los Angeles is introduce herself to her children's teachers and ask how she can be of assistance to the school. She then enrolls in the English as Second Language (ESL) class I taught, and the rest is amazing history.

For the next five years, Rebeca becomes a regular at her children's elementary school. Among other things, she voluntarily sweeps the floors of her children's classrooms three times a week, helps staple papers at the school's office, helps deep clean the school twice a year, tends to the school garden, helps sell snacks after school to raise funds for student field trips, and organizes groups of parents to support families in need within the community; all while making sure her children are clean, well-fed and loved.

Fast-forward ten years, Rebeca’s son, José, has graduated with honors from High School and has been admitted into a four-year University to study engineering. Her daughter Brenda will be graduating — as valedictorian — from High school and is already enrolled in a nursing 
program at the at the local community college. This, according to Brenda, in preparation to later transfer to a four-year university to prepare for medical school. Rebeca too has made progress, she now speaks, reads, and writes English fluently; has earned her GED, and hopes to enroll at the local community college to study something she likes.

As I recall Rebeca's story and the way in which her and her family overcame the obstacles — both big and small — I can't help but be amazed and wonder about the process that makes inspiring stories like Rebeca's possible. More importantly, I ask myself: how do they do it? How do parents with limited resources within less-than-optimal circumstances succeed in getting their children through an educational system that seems designed to make them fail?

My research is inspired by the lives and actions of parents like Rebeca and a total certainty that by looking at these lives closely, we will glean lessons that have the potential not just to reduce academic achievement gaps, but to bring about a wiser, more equitable society. 


\section{Epigraph}

“One cannot expect positive results from an educational or political action program which fails to respect the particular view of the world held by the people. Such a program constitutes cultural invasion, good intentions notwithstanding."

Paulo Freire, Pedagogy of the Oppressed 


\section{Table of Contents}

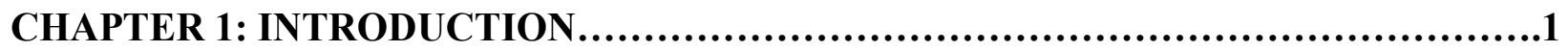

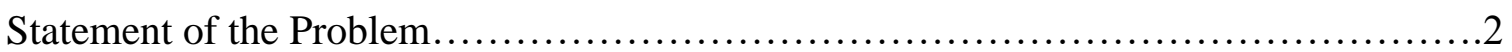

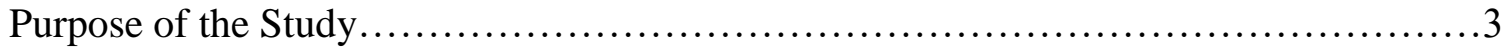

Significance of the Study..................................................4

Research Questions.......................................................6

Implications for Research, Policy, and Practice..................................6

Positionality of the Author...................................................

CHAPTER 2: REVIEW OF LITERATURE.............................................8

Parent Involvement: An Overview........................................ 10

Traditional Paradigms of Parent Involvement.................................................. 10

Latinx Immigrant Parent Involvement......................................14

Alternative Models of Parent Involvement.....................................24

Conceptual Frameworks.................................................................28

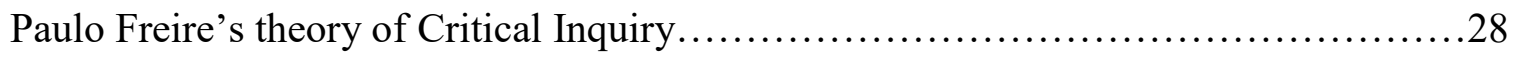

Vygotsky \& Leontiev's Cultural Historic Activity Theory..........................29

Definition of Terms...................................................... 30

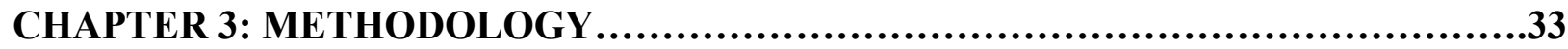

Research Design.......................................................... 33

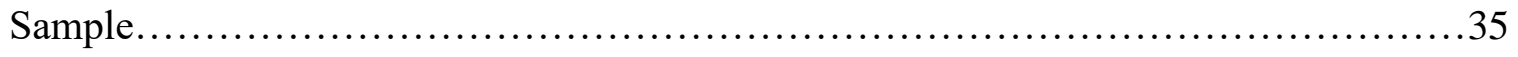

Data Collection...............................................................

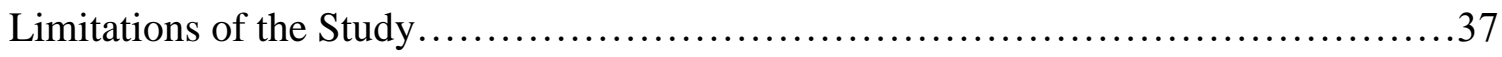




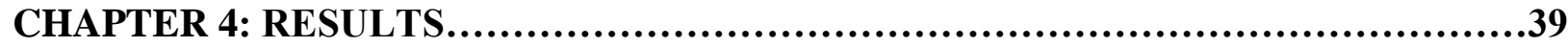

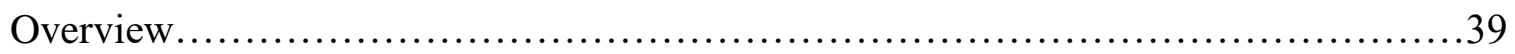

Participants............................................................... 40

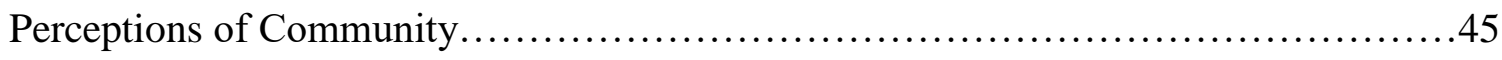

Perceptions of Schools.................................................... 51

Results and Findings: Themes............................................54

Legal Status and Level of Acculturation......................................55

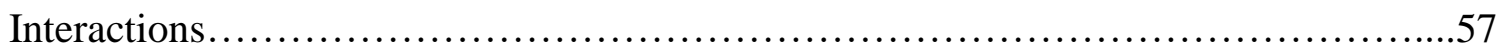

Local and regional policies............................................61

CHAPTER 5: DISCUSSION AND CONCLUSIONS.....................................66

Summary of findings..................................................... 66

Conclusion........................................................... 70

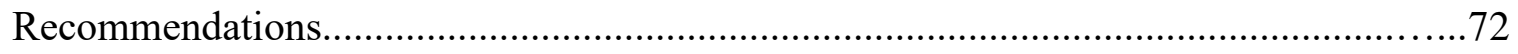

REFERENCES.........................................................................75

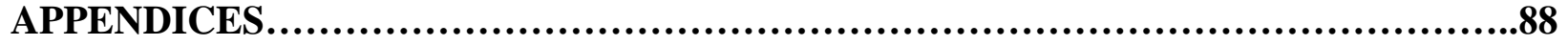

APPENDIX A: Participation Request......................................88

APPENDIX B: Consent Form............................................ 89

APPENDIX C: Demographic Questionnaire................................91

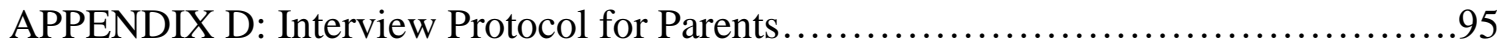

APPENDIX E: Interview Protocol for School and Community Leaders.............. 103

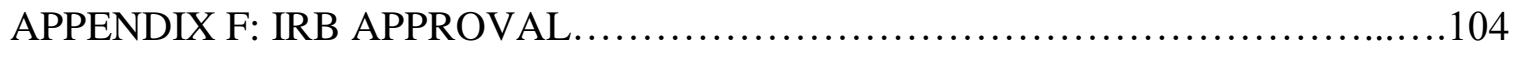




\section{Table of Tables}

Table 1. Model of Parent Involvement...........................................12

Table 2. Participant Demographic Information................................41

Table 3. Crime statistics................................................ 42

Table 4. Parent Perceptions of Community.....................................47

Table 5. Parent Perceptions of School.........................................53

Table 6. Average Visits to School............................................54 


\section{Table of Figures}

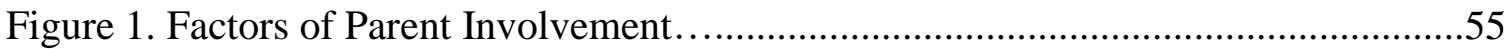

Figure 2. Relationship between Policy and Parent Involvement.......................63 


\section{Chapter 1: Introduction}

\section{Introduction}

The population of students from a home where a language other than English is spoken and who are in the process of developing English proficiency in California has been and remains one of the largest groups of students enrolled in the state's public school system. At the beginning of the $21^{\text {st }}$ century, one of every four students enrolled in a public school in California was classified as an English Learner (EL). Of the approximately 1.2 million ELs currently enrolled in California's public schools, $82.19 \%$ are Latinx ${ }^{1}$ students primarily enrolled in elementary school ${ }^{2}$. Although not all of these students are immigrants, a large majority of them do come from immigrant families.

As trends in EL enrollment are predicted to remain steady, the State of California continues to create and implement programs designed to serve the specific needs of the EL population. However, despite these efforts; Latinx ELs (LELs) continue to lag behind academically. Researchers (Gándara, 2003; Darling-Hammond, 2002; Callahan, 2003; et al.) argue that the low academic achievement of ELs is largely due to an education system that provides fundamentally inequitable education to students based on wealth and language status. This presents a major challenge to all concerned with the education of California's youth. Hence, in responding to the challenge of insuring the academic success of ELs, it becomes necessary to identify, among other things, factors that affect their academic achievement.

\footnotetext{
${ }^{1}$ The term Latinx has, as of recent years, been used in lieu of Latino to include both males and females of Latin American origin.

${ }^{2}$ https://www.cde.ca.gov/nr/ne/yr16/yr16rel38.asp
} 


\section{Statement of the Problem}

Nationwide, the academic performance of LELs consistently falls below that of other students (Abedi \& Dietel, 2004; Impact of No Child Left Behind, 2007; Kindler, 2002; Kohler \& Lazarin, 2007; Lee, 2002; Viadero, 2001). In the 2014-2015 school year, for instance, only 69.4\% of LELs graduated from California high schools. The remaining are still enrolled or have dropped out altogether. ${ }^{3}$ Compared to the $93 \%$ graduation rate of Filipino students or the $88 \%$ graduation rate of White students during the same school year (California Department of Education), the graduation rates of LELs are alarming. Although data on student assessments and graduation rates demonstrate a growing problem, a lack of consensus about what causes the achievement gap and what solutions might close it still remain.

Much of the existing research on academic achievement has addressed variables that schools can control, such as curriculum, best practices, professional development, class size, and funding (Marzano, 2003; Reeves, 2005; Schmoker, 1999). Studies of the academic success of LELs have focused primarily on pedagogical approaches, teacher perceptions and expectations, and cultural and linguistic differences (Y.S. Freeman \& Freeman, 2002; Impact of No Child Left Behind, 2007; Salinas, 2000). Much less research, however, has been conducted on other factors that influence academic achievement.

In their discussion of unequal resources and outcomes, for example, Gándara \& associates (2003) argue with evidence that there are at least seven aspects of the schooling of ELs where students receive an education that is demonstrably inferior to that of English speakers. Segregation, one of the factors mentioned by Gándara and her team, is of particular

\footnotetext{
${ }^{3}$ https://www.cde.ca.gov/nr/ne/yr16/yr16rel38.asp
} 
relevance to this study. Just as ELs are segregated from their English speaking peers, we believe their parents are also ostracized and overlooked by schools.

The experiences of this group of parents and the influence they can have on their children's education, in our view and that of other seasoned researchers (Paris, 2012; DelgadoGaitan, 2004; Perea, 2004; et al.), have been ignored by many and underestimated by most. Sadly, even when research has shown that situating the cultural strengths of family and community within the school curriculum and governance and implementing culturally and linguistically responsive environments can lead to increased and more effective parental involvement (Delgado-Gaitan, 2001; Freire, P., 2002; Gutman \& McLoyd, 2000; CalabreseBarton, 2004; et al.), schools continue to ignore and underestimate Latinx immigrant parents.

\section{Purpose of the Study}

This study attempts to add to the existing literature on parental involvement that, based on unsound comparisons and a deficit perspective, often accuses Latinx parents of not caring enough for their children's education (Valdez, 1996; Ascher, 1988; Carger, 1997; Floyd, 1998; Moles, 1993). Despite evidence showing the importance of parent involvement, extant scholarship on the nature and scope of alternative forms of parental involvement, particularly as it pertains to Latinx immigrant families, still remains limited. Latinx immigrant parents' roles and involvement in schools have been understood mostly in terms of how their actions fit with the goals of the predominant culture of the school. Major challenges faced by Latinx immigrant families such as acculturation (Portes \& Rumbaut, 2000; Suarez-Orozco, 2001; Perez-Carreon, et al., 2005), low levels of income and education (U.S. Census, 2010) and inequitable spaces for engagement (Delgado-Gaitan, 1991) are scarcely addressed in parental involvement research. The approach to understanding parental involvement has relied upon a deficit model, especially 
in discussions of parental involvement in high-poverty urban communities (Gutman \& McLoyd, 2000). Few studies report on initiatives that include parents as equal partners and decision makers.

Hence, prompted by research that demonstrates parent involvement in children's education has a positive impact on academic achievement, social behavior, greater school attendance, and improved social behavior (Williams, D.L. \& Stallworth, J.T., 1984; Desimone, 1999; Epstein, 2001; Hao \& Bonstead-Bruns, 1998; Yan \& Lin, 2005; Anguiano, 2004; Fan \& Chen, 2001; Hill et al. 2004) and a need to offset deleterious effects of a deficit approach in parental involvement research; this study seeks to gauge Latinx immigrant parent experiences and perceptions and the ways in which these affect their ability and/or willingness to engage with their children's schools. More specifically, we seek to 1) learn directly from Latinx immigrant parents about their experiences both in schools and in their communities since 2015, when a wave of blatantly anti-immigrant policies began to flourish, 2) gauge the impact that these experiences have had on their choices to become involved in their children's schools and, 3) present practice implications for educators, policy makers, and parents.

\section{Significance of the Study}

Deficit approaches to teaching and learning have historically viewed the languages and cultural ways of being of many students and communities of color as deficiencies to be overcome in learning the dominant language, literacy, and cultural ways of schooling (Lee, 2007; Paris \& Ball, 2009; Smitherman, 1977, and Valdés, 1996). The dominant culture, which frequently falls in line with White, middle-class norms, positions languages and literacies that fall outside those norms as less-than and unworthy of a place in U.S. schools and society (Paris, 2012). Based on this perspective, it could be said that deficit approaches eradicate the linguistic 
and cultural practices many families of color bring from their homes and replace them with what are viewed as superior practices. These approaches are problematic for at least two reasons: they undermine the contributions immigrant parents can make to their children's education and, more importantly, by ignoring the cultural background of LELs and other underserved, minoritized students, they not only reduce the chances of delivering effective, culturally-responsive education to these students, but also violate the legal rights ELs have to equal education (Mendez v. Westminster, 1946; Brown v. Board of Education, 1954).

Hence, this study is important in that it addresses an urgent need to survey the current context of immigrant families and, because most research on the subject takes a subtractive or deficit approach that devalues the experiences and perceptions of Latinx immigrant parents, it responds to the need for studies that approach the problem from an asset-based perspective that includes the voices of the parents themselves. By examining the narratives of the parents from their own perspectives, this study will not only provide a platform from which their voices can be heard, but will also contribute to create what Gutierrez and collaborators have called $a$ third space (Gutiérrez, Baquedano-Lopez, \& Tejeda, 1999). Within this third space, curriculum that is grounded in the historical and current particulars of students' everyday lives and the home and community practices, histories, and activities (Gutiérrez, 2008) contributes to create a paradigm where the dominant school culture joins with the cultures of families of color in ways that do not devalue either. Thus, in placing genuine equal value on the cultures both of schools and families, the social justice mission of education — which is to provide quality education for all — is being fulfilled. Further, by including Latinx immigrant parents as equal partners, schools may also be enhancing the quality of education ELs receive and, subsequently, their academic achievement. 


\section{Research Questions}

This study set out to answer the following questions:

1. How do Latinx immigrant parents perceive the respective cultures of their children's schools and communities as it pertains to immigrants?

2. How do perceived community and school cultural values affect parents' decisions to engage with their children's schools?

\section{Implications for Research, Policy, and Practice}

As mentioned earlier, the research on Latinx immigrant parental involvement has focused mainly on external factors such as pedagogical approaches, teacher perceptions and expectations, and cultural and linguistic differences. The context within which Latinx immigrant parents form their decisions to engage with their children's schools has been, for the most part, relegated to a footnote by so-called leading researchers (see Literature Review chapter for a discussion of traditional paradigms of parent involvement). A greater emphasis and focus must be placed on the many sociocultural contexts present in culturally diverse families and communities.

Thus, it is our hope that this study will inform district-level policy by illustrating the experiences of Latinx parents and provide additional information to better understand the issue of Latinx parent involvement. It is also our hope that this study will spark interest in further research that genuinely engages the voices and experiences of parents not just in the Latinx community, but in other minoritized, underserved communities of color. Finally, considering the massive exoduses

of people taking place across the planet, this study could potentially prompt interest in international comparative research that looks for ways to effectively educate immigrant students. 


\section{Positionality of the Author}

It is my belief that public education is a primary means of promoting democracy and a more just society. Immigrant families, like other minoritized families who live in poverty, struggle against oppression related to class, race, ethnicity, language, and national origin. Young (1990) described marginalization as a form of oppression. My interpretations of marginalization and oppression are constructed from the many stories and experiences minoritized and immigrant families have shared with me throughout the span of my twenty-year career as a professional educator working in predominantly Latinx immigrant communities and from my own personal experiences as an immigrant woman of color. Being a first-generation immigrant and having lived in underserved communities for most of my life, I have witnessed and experienced the struggles that these communities face first-hand. The meaning I construct from their struggles resonates in my beliefs about social justice. In this study, my perspective on social justice centers on equity in public education (Marshall \& Gerstl-Pepin, 2005). As a supporter of critical approaches, I believe the oppression minoritized families confront on a daily basis must be recognized, named and addressed. 


\section{Chapter 2: Review of the Literature \& Conceptual Frameworks}

Research has found that parent involvement in children's education has a positive impact on academic achievement (Williams, D.L. \& Stallworth, J.T., 1984). Various stake-holders (e.g., teachers, administrators, policy-makers, researchers, etc.) recognize the involvement of parents in their children's education as a beneficially influential factor in promoting higher scores on standardized tests (Desimone,1999; Epstein, 2001; Hao \& Bonstead-Bruns, 1998; Yan \& Lin, 2005), greater school attendance, and improved social behavior (Anguiano, 2004; Fan \& Chen, 2001; Hill et al. 2004). Parent involvement has been shown to be positively related to children's educational performance (Barnard, 2004; Fan \& Chen, 2001; Feuerstein, 2000; Jeynes, 2003; McWayne, Hampton, Fantuzzo, Cohen, \& Sekino, 2004) and may mediate the effects of poverty, parents' educational attainment, and race/ethnicity on achievement (De Civita et al., 2004; Eamon, 2002; Scheiber, 2002). In general, parent involvement has been identified as a possible strategy for reducing the achievement gap (Lee \& Bowen, 2006).

Researchers have concluded that parent involvement generally benefits children's and adolescents' learning and academic success (Hoover-Dempsey \& Sandler, 1997). Studies of programs in early childhood, elementary, middle, and high schools indicate that efforts to improve student outcomes are more effective when the family is actively involved (Henderson and Berla, 1994). Greenwood and Hickman (1991) have cited numerous studies focusing on elementary grades that found relationships between parent involvement and student variables such as academic achievement, sense of well-being, attendance, student attitude, homework readiness, grades, and educational aspirations.

In their work, Gonzalez-DeHass et al. (2005) claim that when parents are involved, students report more effort, concentration, and attention. Students are more inherently interested 
in learning, and they experience higher perceived competence. Students whose parents are involved are more likely to take personal responsibility for their learning. When parents show an interest in their child's education by getting involved, students adopt a mastery goal orientation to learning where they are more likely to seek challenging tasks, persist through academic challenges, and experience satisfaction in their schoolwork. Finally, when parents become involved with students' reading activities, students demonstrate greater self-efficacy as readers, are more motivated to read, and voluntarily participate in literacy activities. (Gonzalez-DeHass et al., 2005).

However, despite evidence showing the importance of parent involvement, extant scholarship on the nature and scope of alternative forms of parental involvement, particularly as it pertains to Latinx immigrant families, still remains limited. Parents' roles and involvement in schools have been understood mostly in terms of what parents do and how their actions fit with the goals of the predominant culture of the school. This approach to understanding parental involvement has relied upon the deficit model, especially in discussions of parental involvement in high-poverty urban communities (Gutman \& McLoyd, 2000). Few studies report on initiatives that have included parents as equal partners and decision makers. Deficit models for understanding parents and education position parents as powerless subjects to be manipulated. They neither take into account the networks of individuals and resources that frame participation in scope, focus, and purpose, nor the unique experiences that frame the parents' beliefs and forge parental capital (Hoover-Dempsey \& Sandler, 1997; Lareau \& Horvat, 1999). In short, parent involvement policies fail to recognize the cultural differences that exist amongst parents (Crozier, 2010). 
The literature reviewed for this study revealed at least two major issues: a lack of common language in the discussion of parent involvement and a prevalent dismissal of alternative practices in parent involvement. With the purpose of better understanding how these issues influence Latinx immigrant parent involvement, this review has been divided into four sections: the first section will focus on the characteristics of and challenges posed by traditional paradigms of parent involvement. The second section, which focuses on models of Latinx immigrant parent involvement - and more specifically, on the barriers that this group of parents encounters both within schools and within society_analyzes current contexts and practices in Latinx immigrant parent involvement. The third section of this review looks at alternative models of parent involvement that offer the possibility of bridging traditional and alternative forms of parent involvement. In closing, section four provides directions for future study of immigrant parent involvement.

\section{Parent Involvement: An Overview}

\section{Traditional Paradigms of Parent Involvement}

Recognizing the important role parental involvement plays in student success, educators, policymakers, and other stakeholders have sought — for at least two decades — to identify parental involvement models that will help bridge the gap between the home and school. Although multiple models have been proposed, only a few have taken root. One of these popular models is Joyce Epstein's School-Family-Community Partnership Model.

Acknowledging parent involvement as an important factor in the quality of a child's education, Epstein's model redefines the relationship between schools, families, and communities as one of overlapping spheres of influence that share a concern about the success of a child (Epstein, 1995). This model, which is comprised of six types of parent involvement 
(Table 1), has been both the subject of praise and criticism and its claims remain under the lens of analysis.

Studies focusing on the relationship between parental homework involvement—one of the components of Epstein's model — and student academic achievement, for example, remain inconclusive. Despite systematic attempts on the part of schools to encourage parents to become more involved with their children on completing homework as a way to improve academic achievement (Cooper 1989, 2001; Cooper et al.2000; Hill and Tyson 2009), the results of research focusing on such efforts remain divided.

In a recent effort to produce a deeper understanding of the relationship between perceived parental homework involvement (i.e., parental homework control and parental homework support), student homework behaviors (i.e., time spend on homework completion, time management, and amount of homework completed), and student academic achievement, a team of researchers that included Epstein (Nuñez, J.C., Suárez, N., et al. 2015) carried out a study that involved 1,683 Spanish students in 10 urban public schools. The sample was comprised of both boys (51\%) and girls (49\%) 10 to 16 years old attending elementary, middle, and high school. Some of the team's findings included a significant relation between homework behaviors, perceived parental homework involvement, and academic achievement. They also found that results vary depending on the students' grade level; specifically, the relationship between perceived parental homework involvement and academic achievement is stronger in junior high and high school than in elementary school. In closing, the team concluded that, because the data in their study were cross-sectional (and not longitudinal nor experimental), no causal conclusions could be drawn (Nuñez, J.C., Suárez, N., et al. 2015). 
Concurrent with the findings of Nuñez, Suárez, et al. (2015), Patall et al. (2008) suggests that different patterns of results may be explained by the fact that parental involvement in homework is more directly related to intermediate variables (e.g., students' cognitions, goals, study habits) than to academic performance. Also in line with this argument, Dumont and colleagues (2012) found that relationships between parental homework involvement and students' motivational outcomes (i.e., academic self-concept and homework behavior) were stronger than the relationship between parental homework involvement and student achievement outcomes.

Table 1. J. Epstein's Model of Parent Involvement

\begin{tabular}{|ll|}
\hline Type of involvement & Definition \\
Parenting & $\begin{array}{l}\text { providing housing, health, nutrition, safety; } \\
\text { parenting skills in parent-child interactions; } \\
\text { home conditions to support study; information to } \\
\text { help schools know child }\end{array}$ \\
School-home/home-school communication \\
Volunteering \\
Teaching at home \\
in school help with classroom/events \\
hecision making \\
hellaborating with \\
choices/options \\
the community
\end{tabular}

Perhaps drawing on the inconclusiveness of the studies done on the relationship between traditional types of parent involvement and student academic achievement, there are those who believe Epstein's and other similar models are short-sighted in that they disregard differentiation across families, add to parental stress, and reinforce social inequity. In Rethinking FamilySchool Relations: A Critique of Parental Involvement in Schooling (2001), Maria de Carvalho defines successful school-family relations as those where administrators, being aware of the 
diversity present in their school communities and understanding the situation of diverse families, use this knowledge to implement school policies that seek to address the needs of all stakeholders. Arguing that, by disregarding the material and cultural conditions of minoritized families, current school-parent partnership models perpetuate the imposition of particular parenting styles (i.e., White, upper-middle class), de Carvalho critiques Epstein's model as being methodologically flawed. The model, Carvalho claims, is based on a small number of schoolfamily-community partnerships and on the characteristics of mostly white, middle-class parents and communities who are already involved with their children's schools (de Carvalho, 2001). Calvalho's claim is sustained, at least in part, by the fact that a considerable portion of Epstein's research-even when looking at school programs and teacher practices in inner city schools (Epstein, 1991) — has been carried out in predominantly white communities where contexts and parent involvement practices tend to be homogeneous and markedly different from those found in underserved communities of color. Policies based on Epstein's model, according to de Carvalho, encourage inaccurate, monolithic views of the family and can result in teachers blaming parents when children struggle academically. Quoting Lareau (2000), de Carvalho reminds readers that low-income parents, with less cultural capital, are not as able to help children succeed academically as well as their White counterparts. Often lacking what Bourdieu (1986) describes as the basic elements of cultural capital—namely linguistic competence and a broad knowledge of cultural and social structures - Latinx immigrant parents operate in an uneven field that sets them at a disadvantage. In closing her argument, and concurrent with research that claims predominant parent involvement paradigms do not account for resource differences in and across parent and family contexts (Tushnet, 2002) or the various rich cultural habits of parents and families (Gonzalez-Mena, 1994), de Carvalho argues that by reinforcing the 
majority culture bias in schools, current parental involvement policies exclude valuable and legitimate interaction patterns of many families and fail to relate to the many sociocultural contexts present in culturally diverse families and communities.

Along the same lines, other critics (Paris, 2001, Souto-Manning \& Swick, 2006; et al.) suggest that as schools continue to call for more parent involvement and claim that state and federal goals are not being met due to lack of parent involvement, it becomes necessary to rethink the very definition of parent involvement and the ways in which higher, more meaningful levels of parent involvement can be attained (Souto-Manning \& Swick, 2006). In other words, a more encompassing paradigm is needed that emphasizes the existing power of immigrant parents and families to create empowerment strategies where these parents can use their skills and talents in diverse environments (Comer, 2001; Heath, 1983; Souto-Manning, 2005).

While the verdict is still out about the ability of mainstream models of parental involvement to bridge the gap between the Latinx immigrant home and school, it is important to highlight the fact that models like Epstein's School-Family-Community Partnership have not only contributed to bring to the forefront the importance of involving parents in their children's education, but have also paved the way for studies that focus on the development of school, family, and community partnerships. Epstein's model reminds us that these partnerships have the potential to improve school programs and school climate, to increase parents'skills and leadership, connect families with others in the school and in the community, and help teachers and administrators with their work (Epstein, 1995). All of which leads to the creation of a caring community around the student, which in turn can lead to student success. 


\section{Latinx Immigrant Parent Involvement}

The rapid growth of Latinx student populations is having an effect on the social composition and overall organization of schools (Trueba, 2004). At the beginning of the $21^{\text {st }}$ century, it was estimated that one of every six children residing in the U.S. lived in an immigrantheaded household (Fuligni, 2001; Landale \& Oropesa, 2005; Suárez-Orozco \& Suárez Orozco, 2000). Large numbers of Latinx immigrant families are non-English speakers from different regions of Latin America and the Afro-Caribbean region. As they spread beyond traditional immigration destinations (i.e., California, Texas, Florida, and New York) into other parts of the United States, these immigrants face the daunting task of becoming acculturated and adapting to new environments. In the process of acculturation, parents must establish new social networks, acquire new forms of cultural capital (e.g., learning English), and learn new skills that will help them access medical, educational, and other vital services for their families. In their discussion of immigrant parents' school engagement experiences, Pérez Carreón \& associates (2005) highlight that adaptation to life in the United States is particularly challenging for poor and undocumented parents because they must cope with the stress of establishing a new life in a culture that welcomes their labor but frequently rejects their presence. Thus, despite sincere efforts to adapt to their new settings, Latinx and other immigrant parents remain outsiders who feel unable to return to their home country because they would not fit in the way they did before they left (Suárez-Orozco \& Suárez-Orozco, 2001). A situation which leads to increased stress and anguish.

The tensions implied in the experience of immigration are further highlighted as parents attempt to engage with their children's schools. While most immigrant parents place a high value on education (Delgado-Gaitan, 1991; Suárez Orozco \& Suárez-Orozco, 2001; Trueba, 1999; Valdez, 1996; Villanueva \& Hubbard, 1994; Villenas \& Deyhle, 1999) and initially express 
satisfaction with their children's schools, they often become frustrated with the educational experiences of their children (Ramirez, 2003; Suárez-Orozco \& Suárez-Orozco, 2001; Trueba, 1999). For instance, parents believe that the curriculum is inappropriate and often view the school environment as hostile or violent. As they attempt to become more actively involved in their children's schooling, parents find that the space for engagement is not equitable and that they have less power than other non-immigrant parents (Abedi \& Dietel, 2004; Delgado-Gaitan, 1991; Meyers, Dowdy, \& Paterson, 2000). Abedi \& Dietel (2004) identify levels of education and economic circumstances as factors that affect the way in which EL immigrant communities adapt to and operate within the U.S educational system. This is particularly problematic for Latinx families where both income and levels of education are lower than that of the general U.S. population. ${ }^{4}$ In their study of immigrant students in American society, Suarez-Orozco et al. (2008) found that among Mexican and Central American families living in the U.S, less than $30 \%$ of mothers and fathers have completed high school and that more than $70 \%$ of these families have a household income of less than 50,000 dollars per year. Low levels of income and education, add Suarez-Orozco \& associates (2008), diminish the confidence of immigrant parents and their ability — due to overemployment and inflexible work schedules— to participate more fully and consistently in their children's education and to take advantage of the resources available at their children's schools.

Because of their limited knowledge of the English language, Latinx immigrant parents find it difficult to communicate with schools to express their views and concerns. Unlike U.S-born parents, who by virtue of their own educational experiences understand the basics of the school system and possess the language capital to organize their school engagement, immigrant parents

\footnotetext{
${ }^{4}$ According to the 2010 U.S Census, $87 \%$ of Americans hold a high school diploma and the median household income is 55,322.
} 
find themselves trying to access and affect a system that was originally unknown to them, while trying to negotiate with an institution that speaks a different language from their own both literally and metaphorically (Calabrese Barton et al., 2004). Hence, as instrument of identity and power, language — or the lack thereof — also plays a role in diminishing the authority and self-confidence Latinx parents had in their home countries (Trueba, 2004). Everyday things like asking a teacher to explain a grade or assignment become barriers that discourage parents from becoming more actively involved in their children's education.

In addition to the language barriers, there are also cultural challenges. The cultural capital of immigrant parents often differs from the forms of capital recognized and valued in the schools (Ruiz-de-Velasco, Fix, \& Chu Clewell, 2000). The unique life experiences and expectations of immigrant parents are frequently overlooked within the predominant cultures of schools. In general, immigrant parents have limited knowledge of school cultures (Delpit, 1988), a limited understanding of the curriculum and organization of U.S. schools, and a lack of awareness of their rights as parents (Delgado-Gaitan, 1990), all of which limit the scope of their participation in their children's education and further contribute to their marginalization.

Finally, isolation, which is often the result of income segregation, makes it difficult for many Latinx immigrant parents to create social support networks that can help them in the process of engaging in their children's schooling (Delgado-Gaitan, 1990; Trueba, 1998). Living in lowincome neighborhoods, argues Galster (2010) in a discussion of the effects of concentrated poverty, can have deep social and geographic effects on the residents of such communities. The neighborhood, for instance, has the potential to affect physical and mental health, sense of efficacy, and material resources. Certain neighborhoods may have little job opportunities appropriate to the skills of their residents, thereby requiring them to look for work outside their neighborhoods and 
often forcing them to engage in long commutes. These time-consuming commutes to and from work, in turn, reduce the amounts of time working parents living in poor neighborhoods spend with their children and/or with each other (Galster, 2010). In many cases, overemployment, inflexible schedules, and long commutes prevent immigrant parents from meeting with other parents or school personnel. Feeling disconnected and marginalized by school actors, Latinx immigrant parents have little motivation to participate in school-parent activities (Ramirez, 2003; Tapia, 2000; Valdez, 1996). It is important to note, however, that in spite of the structural barriers to successful school engagement just discussed, many immigrant parents still manage to position themselves with power-even if this power is limited—within the school space (Trueba, 2004).

Sociologists of immigration have noted that immigrant attitudes are characterized by a general optimism about opportunities in the new setting (Suarez-Orozco, Suarez-Orozco, \& Todorova (2010); Portes \& Rumbaut (2001). Their optimism, determination, strong sense of self, and goal-oriented practices serve as powerful counterforces that help them to not only survive, but also to thrive in less-than-optimal circumstances. The question then arises about what causes some immigrant parents to have more successful school engagement experiences than others. In their discussion of Ecologies of Parental Engagement, Calabrese-Barton and associates (2004) offer a possible answer to this question claiming that successful engagement experiences are not related to parents' personality traits (i.e., some parents can do it and some parents cannot); rather, they are the result of a process in which parents and schools interact in particular spaces, using specific forms of capital, to create a level of engagement that truly benefits a child's school experiences.

With few exceptions, parental involvement literature refers to "parents" in a homogeneous manner paying little or no attention to the experiences of Latinx immigrant parents. It has been proposed that the concept of parental involvement in schooling has not been challenged in school 
discourse or in the literature and that this represents a barrier in the establishment of a common language to discuss the role of parental involvement in schooling (Perez Carreón et al., 2005). Concurrent with other studies (Hill \& Tyson, 2009; Calabrese-Barton et al., 2004), Perez Carreón and associates (2005) argue that parental involvement is a dynamic and ever-changing practice that varies depending on the context in which it occurs. Thus, it should be noted that, as immigrant parents enter traditional spaces of involvement (e.g., parent-teacher conferences, PTA committees, school festival, classroom or office volunteering, etc.) where the awareness of principals and teachers about their feelings and experiences of engagement is minimal or even absent (Hernandez, Denton, \& Macartney, 2008) and where their cultural background and parenting practices are either unknown, ignored, or altogether dismissed; they do so with limited knowledge and power to define their roles or actions (Fine, 1993). Under conditions where parents are expected to passively forfeit their own opinions to conform to the structures already in place, those who comply with what the school demands are seen as "good" and those who dissent are considered “problematic” (Lareau \& Horvat, 1999).

In an unbalanced, top-down parent-school relationship where meaningful opportunities for involvement (e.g., family counseling, adult education programs, and more power in decisionmaking processes) are few (Williams \&Stallworth, 1984), Latinx immigrant parents often feel alienated and, not perceiving the activities organized by the school as feasible alternatives of participation, opt for blindly and unwillingly submitting to the school's demands or ultimately, for not participating at all (Weiss \& Edwards, 1992). The great paradox is that parents who unwillingly choose to engage in the school's formal structures also feel disrespected, distant, and confused in relation to the school's cultural world. Hence, practices in the home and other cultural spaces and the strengths immigrant parents bring to their children's lives are frequently 
unacknowledged and underutilized. Thus, by not knowing Latinx immigrant parents well, schools create barriers that prevent these parents from fully partaking in their children's education.

\section{School-Based Barriers}

In a policy brief published by the Education Public Interest Center, Beatriz Arias \& associates (2008) identified barriers that most often confront EL parents as they engage in their children's education. Among the school-based barriers highlighted by Arias and her team was the deficit approach, which has been cited by numerous other researchers (Freire, 1994; Delgado-Gaitan, 1987; Paris, 2012; Laureau \& Horvat, 2009; et al.) According to Arias (2008), well intentioned plans and projects seeking to support and improve conditions for underrepresented communities often begin by focusing on the weaknesses of such communities and by doing so reinforce the notion that "the problem" should be the focus of attention. This continual focus on "the problem" leads to stakeholders feeling as if all they have are problems or communities believing that all they have are deficits (Green \& Haines, 2012). As a result of this negative mindset, a widespread belief may start to settle in about the individuals in a community being dysfunctional and just filled with problems — all of which further complicates the initial situation.

More specifically within the context of this study, the deficit approach causes schools to view the languages, literacies, and cultural ways of being of many students and communities of color as deficiencies to be overcome in learning the demanded and legitimized dominant language, literacy, and cultural ways of schooling (Lee, 2007; Paris \& Ball, 2009; Smitherman, 1977; and Valdés, 1996). The dominant language, literacy, and cultural practices demanded by schools, in turn, fall in line with White, middle-class norms that position languages and literacies that fall outside the status-quo as less-than and unworthy of a place in U.S. schools and society 
(Paris \& Ball, 2009). The goal of deficit approaches, argues Paris (2012) in his radical discussion of culturally sustaining pedagogy, is to eradicate the linguistic, literate, and cultural practices many students of color bring from their homes and communities and to replace them with what is viewed as superior practices. Be as it were, this is particularly relevant in immigrant communities where the deficit perspective often leads educators to view culturally and linguistically diverse students and their families as "the problem" rather than to consider and remedy their own deficiencies in working with diverse populations (Gibson, M.A., 2002). Latinx immigrant parents are frequently perceived as completely devoid of resources (e.g., experience, know-how, and education) to provide and support home educational experiences for their children (Fine, M., 1993; Finders, M. \&Lewis, C., 1994).

Within the deficit approach, alternative forms of cultural capital such as nurturing, instilling cultural values, talking with their children, and sending them to school clean and rested (Valdés, 1996) and the personal resources (positive attitudes, optimism, motivation, and persistence) (Arellano \& Padilla, 1996) Latinx EL parents bring to their children's education are underestimated, dismissed, and at times completely ignored by teachers and other school actors. Teacher biases and limited knowledge about LEL parents contribute to create unhealthy dissonance between teachers and parents (Swick, 2004). Even when teachers say they believe in parent involvement, when confronted with a parent who sees things differently or who challenges their authority, they often react defensively (Gonzalez-Mena, 1994). Teacher beliefs and perceptions — which are influenced by current and past contextual and cultural elements (Powell, 1998) — position immigrant parents and their families as subordinates to the predominant culture (Souto-Manning \& Swick, 2006). 
This deficit perspective suggests that fault and responsibility lie completely with the EL population rather than with the school, and that the role of the school is to change the ways families interact with schools. With little or no awareness of alternative forms of involvement, many educators assume that lack of or low EL parental participation is evidence of total absence of parental interest (Ascher, C., 1988; Carger, C.L., 1997; Floyd, L., 1998; Moles, O.C., 1993) and, in doing so, these educators contribute to create cultural chasms in which "us vs. them" mentalities sustain the perpetuation of harmful hegemonic, monocultural, and monolingual policies and practices.

\section{Barriers Beyond the School}

In the discussion of parent involvement in minoritized communities beyond the local (school) context, educational scholars have called for an analysis of the ways in which race and language intersect with culture and social institutions. Drawing upon the Critical Race Theory (CRT) notion that power differences and conflicts that parents from language and ethnic minority backgrounds often experience are due to the multiple manifestations of culture in school settings, Calabrese-Barton \& associates (2004) argue that schools tend to maintain the ideals and beliefs of a capitalist culture, positioning the cultures of poor, minoritized, immigrant, and linguistically diverse families as subordinate. As Villenas \& Dehyle (1999) point out in their study of CRT and secondary education, both the macro- and microenvironments of schooling are permeated with cultural values that allow the manifestations of racist beliefs to take on both institutional and individual forms. Hence, what happens outside the schools inevitably and directly affects what happens in schools.

Recent developments such as the institution of English-only policies; narrow, decontextualized language and literacy programs in poor communities of color; and even the 
banning of ethnic studies (see Arizona House Bill 2281) are examples of the return of explicit deficit perspectives, policies, and pedagogies (Nieto, 2011; Paris, in press).

Adding to the challenges Latinx immigrant and other minoritized parents and communities already face is an increase in blatantly overt racist, anti-immigrant sentiments and policies that have been propagated throughout the U.S. by politicians like Donald Trump in the last few years. From describing undocumented Mexican immigrants as criminals, drug dealers, and rapists ${ }^{5}$ who have caused the decline of the U.S. economy ${ }^{6}$ to referring to Syrian refugees as a "Trojan horse" that will spawn future terrorist attacks ${ }^{7}$, Trump and other like-minded politicians have contributed to create increasingly hostile environments for immigrants (Gándara $\& \mathrm{Ee}, 2018)$.

In a recent study carried out by the Civil Rights Project on the impact that U.S. immigration enforcement policy has had on the nation's schools, Gándara and Ee (2018) found that schools that struggle the most to close achievement gaps-i.e. schools with large immigrant and/or EL populations - are being hit the hardest by the enforcement of anti-immigrant, fearinducing policies and tactics. Both immigrant and non-immigrant students and their teachers are being affected in significant ways.

According to the Civil Rights Project report, almost 90\% of administrators surveyed reported observing an increase in behavioral or emotional problems in immigrant students.

\footnotetext{
${ }^{5}$ https://www.youtube.com/watch?v=Jaz1J0s-cL4

${ }^{6}$ Donald Trump on Immigration Reform. Blame Mexico! The Economist (Aug. 18, 2015), https://perma.cc/64YU$3 T Z 6$.

${ }^{7}$ Donald Trump on Syrian refugees. Donald Trump warns that Syrian refugees represent a 'great Trojan horse' to the U.S. The Los Angeles Times (Oct. 19, 2016) http://www.latimes.com/politics/la-na-pol-syrian-refugees-debate20161019-snap-story.html
} 
Across all regions, $84 \%$ of educators noted students expressing concerns about immigration enforcement issues at school and $70 \%$ of both administrators and certificated staff reported academic decline and increased absenteeism among immigrant students. The investigators also found that parent involvement has declined out of parents' fear of leaving the home and fear that the schools could be cooperating with immigration officers. These findings are especially troubling considering that, in addition to living with the common stressors that non-immigrant families experience, immigrant students and families also face the psychological challenges that come with migration and acculturation. An increase in stress could have unforeseen effects in predominantly immigrant communities and in society in general. Furthermore, additional academic decline and increased absenteeism in communities where academic achievement and attendance were already low could aggrandize existing achievement gaps and possibly increase the percentage of EL students dropping out of school. Unfortunately, despite the fact that $88 \%$ of the educators surveyed by Gándara \& Ee (2018) recognized a need on the part of schools to address these issues in community forums, relatively few schools have actually done so (Gándara $\& \mathrm{Ee}, 2018)$

\section{Alternative Models of Parent Involvement}

Unlike predominant, traditional models which tend to dictate to parents rather than interact with them, non-traditional models of parental involvement are more interested in developing relationships between parents and schools where information flows constantly and meaningfully in both directions. Situating the cultural strengths of family and community within the school curriculum and governance, these models include parental empowerment and integration of community into school curriculum and operations. Generally, examining the issue from a perspective that takes into account context and power dynamics, proponents of these 
alternative models (Delgado-Gaitan, 2001; Freire, P., 2002; Gutman \& McLoyd, 2000; Calabrese-Barton, 2004; et al.) agree that in order to create the culturally and linguistically responsive environments that are conducive to increased and more effective parental involvement, schools need to develop parental involvement programs that support families, promote communication, and advocate for the empowerment of parents.

As feasible alternatives, educational researchers have proposed parental involvement policies and practices designed particularly for low-income, minoritized communities. James Comer's (1984) School Development Plan, for example, challenges common teacher-dominant paradigms of family involvement in which the teacher is always in the decision-making role. Comer's plan advocates for parental participation at all levels and for a partnership approach where parents, regardless of their cultural and socioeconomic background, perceive themselves and are treated as equal partners by teachers and administrators. In the same vein, in a study done in urban, low-income schools, O'Connor (2001) found that including parents in decisionmaking processes and providing them with learning communities not only empowers and guides parents, but also facilitates the involvement process. Therefore, in addition to supporting families and promoting more effective forms of communication, schools also need to change existing imbalanced power relations between educators and low-income and other minoritized parents (Abrams \& Gibbs, 2002).

Moving beyond what they call "a laundry list of things that good parents do for their children's education," Calabrese-Barton \& associates (2004) make a case for a new data-driven framework for understanding parental engagement in urban elementary schools, the Ecologies of Parental Engagement (EPE). By shifting the focus from what parents do to engage with their children's schools and with other actors within those schools, to also considering how parents 
understand the processes and rationale of their engagement, and how this engagement relates more broadly to their experiences and actions both inside and out of the school community, the EPE framework marks a fundamental shift in the process of understanding parent involvement. Calabrese-Barton \& associates (2004) situate parental engagement as a relational phenomenon that relies on activity networks and highlight the importance that both space and capital play in the relative success schools have in engaging parents. Turning away from the term "involvement," which in the authors' view implies passive submission or "reaction", the proponents of EPE use the word "engagement" to include not only parent participation in school events, but also the situations or contexts that surround an individual's decision to participate.

Hence, by conceptualizing parental involvement that frames parents as both authors and agents in schools and by presenting parental involvement as a dynamic, interactive process in which parents draw on multiple experiences and resources to define their interactions with schools and among school actors (Calabrese-Barton, et al.), the proponents of alternative models of parent involvement give evidence of the potential to create meaningful parental involvement within immigrant and other minoritized communities that does not further discrimination. In doing so, these models contribute to minimize the effects of the deficit approach and equip parents and schools with the necessary tools to confront the barriers they face both within individual schools and more broadly within society.

\section{Directions for future study of EL Parent Involvement}

Considering the seriousness of the problem at hand, there is an urgent need-more than ever under current circumstances - to expand the investigation on Latinx immigrant parent involvement. In the process of writing this review, two main areas have been identified as requiring 
further study: the nature, purpose and validation of alternative forms of capital among EL communities and the manifestations of culture at individual schools.

A thorough analysis of the nature and function of alternative forms of capital manifested by EL communities will not only provide teachers, administrators, policy makers, and parents with valuable information and tools they can use to create culturally-sustaining programs and schools, but will also serve to counteract forces that methodically seek to turn what is already a diverse, multicultural, and multilingual society into one that is monocultural, monolingual and Whitecentered. In the face of current policies that seek to turn back the clock, exhorts Paris (2012), research and practice need equally explicit resistances that embrace cultural pluralism and equality.

Likewise, further studies that focus on the manifestations of culture in schools will aid in understanding the complex and dynamic forces that shape and guide schools' policies and practices. This understanding, in turn, has the potential to improve communication between parents and other school actors and to create more equitable school environments.

\section{Summary}

The completion of this review of the literature on parent involvement yielded a clear conclusion that much remains to be done in the effort to effectively and meaningfully increase involvement of Latinx immigrant parents in their children's schools. From policy to practice, there is much of what is known and accepted as fact about immigrant families and students that needs to be revisited and modified.

There is an urgent need to dispel negative stereotypes that assume Latinx parents do not care for the education of their children and that lead to unjustifiable prejudices. As Portes \& Rumbaut (2001) explain, all too often, immigrant families are painted with broad strokes that 
neglect differences and input motives and values quite at variance with reality. These misguided perceptions, in turn, often lead to unjustifiable prejudices that equivocally inform and guide educational policy, teacher training, and the way in which schools function. More importantly, there is an urgent need to develop a new, broader vision of the concept of parent involvement that takes into account the cultural and social capital and current contexts of all parents. This vision, by necessity, must include the voices of the parents. For without the parents' voices, parent involvement will remain a top-down, lopsided endeavor in which parents-especially those in underserved communities — find no meaning, relevance or ownership.

\section{Conceptual Frameworks}

Inasmuch as constructivism provided the epistemological view for this study, our conceptual framework was grounded in two theoretical perspectives: Critical Inquiry (Freire, 1972) and Cultural Historic Activity Theory (Vygotsky \& Leontiev, 1920). While Freire's theory of critical inquiry — which emphasizes the importance of giving voice to marginalized peopleserved as philosophical touchstone for this study, Vygotsky \& Leontiev's theory of cultural historic activity, which highlights the importance of social context, provided the foundation for the design of this study.

\section{Critical Inquiry}

In his discussion of meaning and perspective in the research process, Crotty (1998) described critical inquiry as an ongoing project that includes reflection and action to create a

more just and freer society. Central to this theory are relationships between power, privilege, and oppression (Crotty, 1998). As mentioned earlier, considering that the approach to studying Latinx immigrant parent involvement has been dominated by deficit perspectives (see Literature 
review chapter section on traditional paradigms of parental involvement) that favor the views and choices of the dominant culture over those of minoritized parents, Freire's theory, which calls for full participation of all stakeholders, seems adequate in a study seeking to gauge Latinx immigrant parent experiences and perceptions and the ways in which these have affected their ability and/or willingness to engage with their children's schools. In other words, critical inquiry creates the space within which Latinx immigrant parents as minoritized, underrepresented elements of society can sit at the discussion table to reflect, share their experiences, and participate directly in a dialogue about their children's education, and more specifically about the ways in which the dominant culture - which generally tends to omit their experiences and views - may be precluding them from participating more actively in their children's education.

\section{Cultural Historic Activity Theory (CHAT)}

Cultural-historical activity theory, which traces its origins to the founders of the culturalhistorical school of Russian psychology L. S. Vygotsky and Aleksei N. Leontiev, is a theoretical framework which helps to understand and analyze the relationship between the human mind (what people think and feel) and activity (what people do) (Kaptelinin \& Nardi, 2006). In discussing the dynamics of consciousness, Vygotsky's states that consciousness is essentially subjective and shaped by the history of each individual's social and cultural experience (Vygotsky, 1978).

Applying cultural-historical activity theory to parental involvement centralizes how and why social context matters. Social organizations, such as schools and community-based organizations, are embedded with cultural values. These values manifest themselves in recurring social practices and their artifacts that give order, purpose, and continuity to life in that social organization. In education, states Roth (2004), it is often assumed that parent-school official 
interactions naturally move parents, teachers, and children toward a shared optimal outcome such as the academic development of the child. Activity theory, however, by exposing the multidimensioned and interactional nature of activity, explains how movement toward a shared ideal is enabled and constrained by the normalized social practices that exist within an organization and the players, values, and tools that facilitate that practice (Roth, 2004).

Thus, an in-depth understanding of parental involvement requires the study of parents' practices in relation to the beliefs that motivate and sustain these practices. Practices of parental involvement, in turn, must be studied in connection to the spaces in which this involvement takes place. In line with CHAT's stance that humans purposefully transform natural and social reality as an ongoing culturally and historically situated process (Roth \& Lee, 2007), parent practices are transformative in that they not only affect the parents' own sense of the world (in this case, the schooling world), but also shift the dynamic structures and boundaries of the spaces in which actions take place. Put differently, parents are positioned in specific ways not only by their own perceptions and beliefs, but also by the discourses and actions of other school actors with whom they converge in specific spaces and situations (Pérez-Carreón, 2005). The concept of parental involvement, explain Calabrese Barton \& associates (2004), goes beyond an individual and his or her participation in an event. It also includes the situations or contexts involved in an individual's decision to participate in an event, including his or her relationships with other individuals, the history of the event, and the resources available to both the individual and the event designers.

Consequently, in our effort to analyze the contexts within which minoritized Latinx immigrant parents make their decisions to partake in their children's education and to give these 
parents a voice, choosing Freire's theory of Critical Inquiry and Vygotsky's Cultural Historic

Activity Theory made natural sense.

\section{Definition of Terms}

Culture: The customary beliefs, social forms, and material traits of a racial, religious, or social group; also: the characteristic features of everyday existence (such as diversions or a way of life) shared by people in a place or time (Webster Dictionary).

English Learner (EL): English learners, as defined by California's Department of Education, are those students for whom there is a report of a primary language other than English on the state-approved home language survey and who, on the basis of the state approved oral language (grades kindergarten through grade twelve) assessment procedures and literacy (grades three through twelve only), have been determined to lack the clearly defined English language skills of listening comprehension, speaking, reading, and writing necessary to succeed in the school's regular instructional programs. Although some government reports both at the federal and state level often refer to this group of students as Limited English Proficiency (LEP), for the purpose of this study and to avoid superlative terminology that can have perjorative effects, the term EL will be used to refer to students whose first language is not English. Note that we use the term EL with reservations due to the fact that these students are not successfully learning English and that this term implies a deficit on the part of students.

Family: In addition to the traditional definition that describes "family" as a support system involving two married individuals providing care and stability for their biological offspring (Webster Dictionary), our definition will extend to also include groups of people who, 
regardless of biological connections, marital status, or gender of parents/care-givers, show consistent caring and support for each other.

Immigrant: a person who relocates permanently to live in a foreign country.

Latinx: in lieu of the traditional "Latino" which was used to refer to peoples of Latin American origin, the non-binary term Latinx has been, as of recent times, been used to include Latin Americans of both genders.

Parents: For the purposes of this study, the term parents will be used to include all those who are the children's permanent caregivers in the home. Some caregivers, such as grandparents, aunts, uncles, or older siblings, may be biologically related to children. Other caregivers, however, may not be biologically related; rather, they may be legally appointed guardians or persons who were entrusted by one or both of the biological parents with the raising of the children.

Parent involvement: In addition to the definition found in J. Epstein's multidimensional framework of parental involvement (see table 2), this study will also define the term as "the presence of parents in their children's schooling, regardless of whether that presence is in a formal school space or in more personal, informal spaces, including spaces created by parents themselves" (Pérez- Carreón, Drake \& Calabrese, 2005) and, in accordance with the No Child Left Behind legislature, it will also describe parent involvement as the participation of parents in regular, two-way, and meaningful communication involving student academic learning and other school activities. 


\section{Chapter 3: Methodology}

\section{Research Design}

The purpose of this study is to identify and explore the experiences of Latinx immigrant parents in the last three years and to analyze and discuss the effects that anti-immigrant policies have had on the social and cultural contexts that underlie parents' decisions to become involved in their children's schools.

Because the nature of our research question is related to gaining understanding and explaining meaning, we use qualitative methods of research which have been defined as "an inquiry process of understanding based on distinct methodological traditions of inquiry that explore a social or human problem" (Cresswell, 1998). The intention is to study parents in their own environment and to record their perceptions of the cultures of their children's schools and communities and the way in which these perceptions influence their actions. With the purpose of identifying possible unifying meanings, this study employs a phenomenological approach; which has been defined as "a research strategy of inquiry in which the researcher identifies the essence of human experiences about a phenomenon as described by participants" (Patton, 2002) and as an exploration of the subjects' lived experiences (Creswell, 2007). A phenomenological approach seems appropriate for this study because it allows us to collect the diverse perspectives and experiences of the participants, which, according to Cresswell (2009), is one of the best ways to understand how experiences influence beliefs.

\section{Procedures}

Two elementary schools with high enrollment of English Learners (ELs) in the city of Pomona, California were selected. Emails describing the study were sent to individuals and organizations that could help identify potential participants. Once qualified participants were 
identified, they were contacted via telephone calls and arrangements were made for them to receive a full, written description of the study and a Participation Agreement (Appendix A). Once all questions about the study were answered and all agreements had been signed, interview dates were scheduled.

Initially, two separate individual interviews — carried out completely in Spanish—were done with participants to gather demographic information and to document their experiences and perceptions of their children's school cultures. With the intention of establishing trust, these interviews were carried out in person in places and at times designated by participants; such as restaurants, other people's homes, and participants' own homes. This was particularly important given the sensitive nature of some of the information (e.g. legal status) being shared. A third meeting in the shape of a focus group was carried out with the intention of giving participants an opportunity to engage with each other and with the investigator to expand the dialogue and to develop on ideas encountered during the initial interviews. Three participants attended this meeting. The remaining two parents were unable to attend due to personal reasons. Participants chose to meet at a local swap-meet for this 1 hour meeting. Lastly, to allow the opportunity for expansion and/or clarification, hard copies of their respective interview transcripts were given to each parent.

\section{Instrumentation}

In keeping with research that states parental involvement should include not just participation in school events, but also the situations or contexts involved in an individual's decision to participate in such events (Calabrese Barton \& associates, 2004) and with the final objective of gauging their perceptions and experiences, we asked parents to fill out a demographic questionnaire (Appendix C) and to answer an initial set of questions (Appendix D) 
that focused on their perceptions of the attitudes demonstrated by school staff and community leaders toward Latinx immigrant families. A second set of questions (Appendix D) was carried out with parents to determine how their perceptions affect their choices to become involved at their children's schools. The purpose of this second round of questions was twofold: to help determine the relationship between parents' perceptions and the development of their behaviors, and to explore changes in their involvement from 2015 to the present. Finally, with the purpose of triangulating data gathered from parents, we included two interviews with school and community leaders (Appendix E). The first interview was carried out with the Principal of Pennsylvania Elementary school and the second with Pomona's city council member Cristina Carrizosa. Both of these interviews were carried out at the respective offices of these individuals.

\section{Sample}

A purposive sample was used in order to accommodate the needs of our study. Participants were recruited via personal and professional contacts (administrators, principals, teachers, etc.) and community organizations (Adult Education centers, social and athletic clubs, churches, etc.) Because our study focuses on socioeconomically challenged parents, only families with annual income equal to or lower than the established federal minimum living wage standard were included. Additionally, only parents that migrated to the U.S. after the age of 12 were included because their level of acculturation would be so that they could still be classified as immigrants.

The participants for this study were purposively selected from Pennsylvania and Kentucky Elementary Schools (names have been changed to protect the identity of the participants). These schools were chosen because of their high enrollment of English Language Learners. The participating group was initially comprised of eight Latinx immigrant families. 
The goal was to gain participation from all eight families that were contacted (and that had already signed participation agreements). Unfortunately, two of the families opted out of the study before it began and a third withdrew after completing the demographic survey. Two of the withdrawing families cited personal circumstances as reasons for leaving the study and the third gave no reason or explanation. Thus, the study was carried out with five families; three from Pennsylvania Elementary School and 2 from Kentucky Elementary. Whenever available, both male and female parents were invited to participate. All four available male parents declined to participate. One cited conflicting work schedule as reason for not participating. The remaining three said they were "too tired after work" and stated a belief that school matters are better left to their wives.

\section{Data Collection}

All interviews were recorded through a digital audio recorder. Interviews were transcribed manually by the principal researcher and then reviewed for accuracy by a bilingual education professional who possesses vast knowledge in the field of research methods. This last step was taken in an effort to ensure trustworthiness.

The data gathered through interview transcriptions was first coded using a content analysis approach (Bryman, 2012). Using Bryman's four stages of qualitative analysis as guide, data was coded systematically to identify themes and to produce patterns from the interviews. During the first stage of analysis, the researcher re-read all transcripts with the intent of identifying and documenting themes and categories to produce an initial analysis. At this point, major themes were identified and responses were grouped into categories. After several careful readings of the transcripts, during the second stage of analysis, we created a coding scheme and highlighted key words and sentences, which led to the 
identification of broader themes. This manual coding was done in keeping with claims (Strauss, 1987) that manipulating data on paper and writing codes manually helps the researcher to remain closer to the qualitative data. At this point, looking at the interactions among responses within the same school and between schools, accounting for the frequency of similar responses, and identifying outlier responses provided us with deeper insights of the data.

Finally, to further ensure trustworthiness, credibility, and validity, a peer debriefing was done with two colleagues and as stated before, a member check meeting was held to obtain feedback and comments from participants of the study (Cresswell, 2012).

\section{Protection of Human Subjects}

Human subjects were not harmed in the process of carrying out this study. Institutional review board (IRB) permission was secured through the IRB committee at Claremont Graduate University (Appendix F). This permission was required to make sure appropriate protocol was followed to protect the rights of participants in the study (Grady, 2010). Participants received extensive information both verbally and in writing (See appendix B) on the nature and process of the study before, during, and at the end of the process. All demographic and contact information provided by participants will be kept confidential and names of participants, if used, will be substituted with pseudonyms. Having understood their rights, all participants agreed to participate in the study.

\section{Limitations of the Study}

There are at least three perceived limitations to consider while reading this study. First, the study's briefness may represent a challenge in that it only covers the past 3 years. It is our belief that, because the data in our study were cross-sectional (and not longitudinal or 
experimental), causal conclusions are difficult to draw. The second limitation is related to instrumentation. There may exist a challenge in instrument decay because the main source of information will be retroactive — parents will be asked to recall past experiences and thoughtstherefore, the information may not be as accurate as it could have been in a longitudinal study. The third limitation is related to size and geographic scope. Because the sample is comprised of only 5 families in a relatively small city in Southern California, the size and geographic location of the sample may also prove problematic in generalizing the results to similar populations outside of Southern California. The trustworthiness of the study could, therefore, be strengthened by increasing the size of the sample and by extending the study to include other key geographical areas in California. 


\section{Chapter 4: Results}

\section{Overview}

This chapter analyzes data obtained to identify key themes, underlying ideas, and assumptions related to the ways in which Latinx immigrant parent experiences and perceptions affect their ability and/or willingness to engage with their children's schools. More specifically, this section seeks to answer the questions that guide this study: 1) How do Latinx immigrant parents perceive the cultures of their children's schools and their communities as it pertains to immigrants? 2) How do perceived community and school cultural values as it pertains to Latinx immigrants affect parents' decisions to engage with their children's schools? Stated differently, the objective of this study was to learn directly from Latinx immigrant parents about their experiences both in schools and in their communities since 2015, when a wave of blatantly antiimmigrant policies began to flourish and to gauge the impact that these experiences have had on their choices to become involved in their children's schools.

The five women participating in this study gave different reasons for choosing to remain involved with their children's schools. Upon completing the analysis of the data, it became evident that there were common factors like legal status, level of acculturation, and local and regional politics that play a decisive role in parents' choices to become or remain involved with their children's schools. The two women who reside legally in the U.S demonstrated more confidence than their undocumented counterparts in becoming involved. At the same time, the level of acculturation, regardless of legal status, also played an influential role in determining parental involvement. Lastly, the dynamics of local politics also played an important role. The latter part of this chapter will describe in depth the reasoning that supports these claims. 
In order to provide context for the discussion of the findings, this chapter begins with a brief description of the participants and their communities. In the second part of this chapter, we present the data gathered and engage in an analysis of the themes that emerged as a result of the study.

\section{Participants}

Through this qualitative, phenomenological study, we explored, described, and analyzed the experiences and perceptions of five Latina immigrant mothers. Three of the participants had at least one child attending PES and the other two had children enrolled at KES. The final group of participants was comprised of four married women and one who is divorced and estranged from her daughters' father. Four of the participants migrated from Mexico and the fifth came from Honduras. Two of the participants reside legally in the U.S. and three reported not having legal documentation that authorizes them to live and work in the country. All participants reported having limited or no knowledge of the English language. The ages of the participants ranged from 30 to 50 . When asked about their employment status, four of the five participants reported not working outside of the home and one reported working at her own business at least 40 hours per week. The educational level of the group ranged from middle-school to some college; four of the participants studied only in their home countries and one studied two years of high school in the U.S. The time lived in the U.S. by the participants ranged from 8 months to 35 years. Three reported having lived only in Pomona for the entire duration of their stay in the U.S. and two reported having lived in other states. Lastly, all families—which ranged from 3-5 members-reported having annual household incomes that range between one thousand and three thousand dollars per month. (Table 2) 
Table 2. Participant Demographic Information

\begin{tabular}{|c|c|c|c|c|c|}
\hline & $\mathbf{A}$ & $\mathbf{B}$ & $\mathbf{C}$ & $\mathbf{D}$ & $\mathbf{E}$ \\
\hline Gender & Female & Female & Female & Female & Female \\
\hline Marital status & Married & Divorced & Married & Married & Married \\
\hline Age & $50+$ & $40-50$ & $30-40$ & $40-50$ & $30-40$ \\
\hline Country of origin & Mexico & Mexico & Mexico & Mexico & Honduras \\
\hline Time living in the U.S. & 35 years & 20 years & 22 years & 5 years & 8 months \\
\hline Time living in Pomona & 3 years & 5 years & 5 years & 5 years & 8 months \\
\hline Educational level & $\begin{array}{l}\text { Primary } \\
\text { School }\end{array}$ & $\begin{array}{l}\text { High } \\
\text { School }\end{array}$ & $\begin{array}{c}\text { Some } \\
\text { College }\end{array}$ & $\begin{array}{l}\text { High } \\
\text { School }\end{array}$ & $\begin{array}{l}\text { Middle } \\
\text { School }\end{array}$ \\
\hline $\begin{array}{l}\text { English language } \\
\text { proficiency (self- } \\
\text { reported) }\end{array}$ & None & Below basic & Basic & $\begin{array}{l}\text { Below } \\
\text { basic }\end{array}$ & None \\
\hline Housing situation & Rent & Rent & Shared & Rent & Rent \\
\hline $\begin{array}{l}\text { Work outside the } \\
\text { home }\end{array}$ & No & No & $\begin{array}{c}\text { Yes } \\
40 \text { hrs. per } \\
\text { week }\end{array}$ & No & No \\
\hline $\begin{array}{l}\text { Household monthly } \\
\text { income }\end{array}$ & $\begin{array}{c}\text { 2-3 } \\
\text { Thousand }\end{array}$ & $\begin{array}{c}1-2 \\
\text { thousand }\end{array}$ & $\begin{array}{c}1-2 \\
\text { thousand }\end{array}$ & $\begin{array}{c}2-3 \\
\text { thousand }\end{array}$ & $\begin{array}{c}1-2 \\
\text { thousand }\end{array}$ \\
\hline Residence status & Legal & Not Legal & Legal & Not Legal & Not Legal \\
\hline Members of household & 5 & 3 & 5 & 4 & 4 \\
\hline
\end{tabular}

\section{Demographics}

In an effort to provide readers with a context in which they can place this study and follow the connections discovered along the way, we have included demographic and other relevant information not only about the schools in which we worked, but also about the community (District 3) in which our schools are located and more broadly about the city of Pomona.

\section{Pomona}

Pomona is a city in Los Angeles County in California. It is located in the Pomona Valley, between the Inland Empire and the San Gabriel Valley and it is home to more than 140,000 people. As of the 2010 U.S. Census, 70.6\% of Pomona's residents were of Latinx origin and $34.1 \%$ were reported as having been born in a foreign country. That is, more than one third of Pomonans are immigrants. Economically, Pomona was reported to have a median household income of 49,474; with $21.6 \%$ of its population living below the federal poverty line. According 
to information provided by the Pomona Police Department, the crime index of the city (329) in 2016 was higher than the U.S. average at the same time (280.5). When looking at violent crimes, Pomona's crime rate is $24 \%$ higher than the California average and $46 \%$ higher than the national average $^{8}$. Worth noting for the purpose of this study is the fact that crime rates within Pomona are consistently higher in the southeast part of the city which includes city district 3, where both of our participating schools are located. Also, worth noting is the fact that reporting district 84; the immediate area where our participating schools are located, has seen consistent patterns of growth in criminal activity (Pomona Police Department, 2014). From 2010 to 2013, for instance, this district saw an increase of $42.2 \%$ in criminal activity. (Table 3 )

Table 3. Crime Statistics

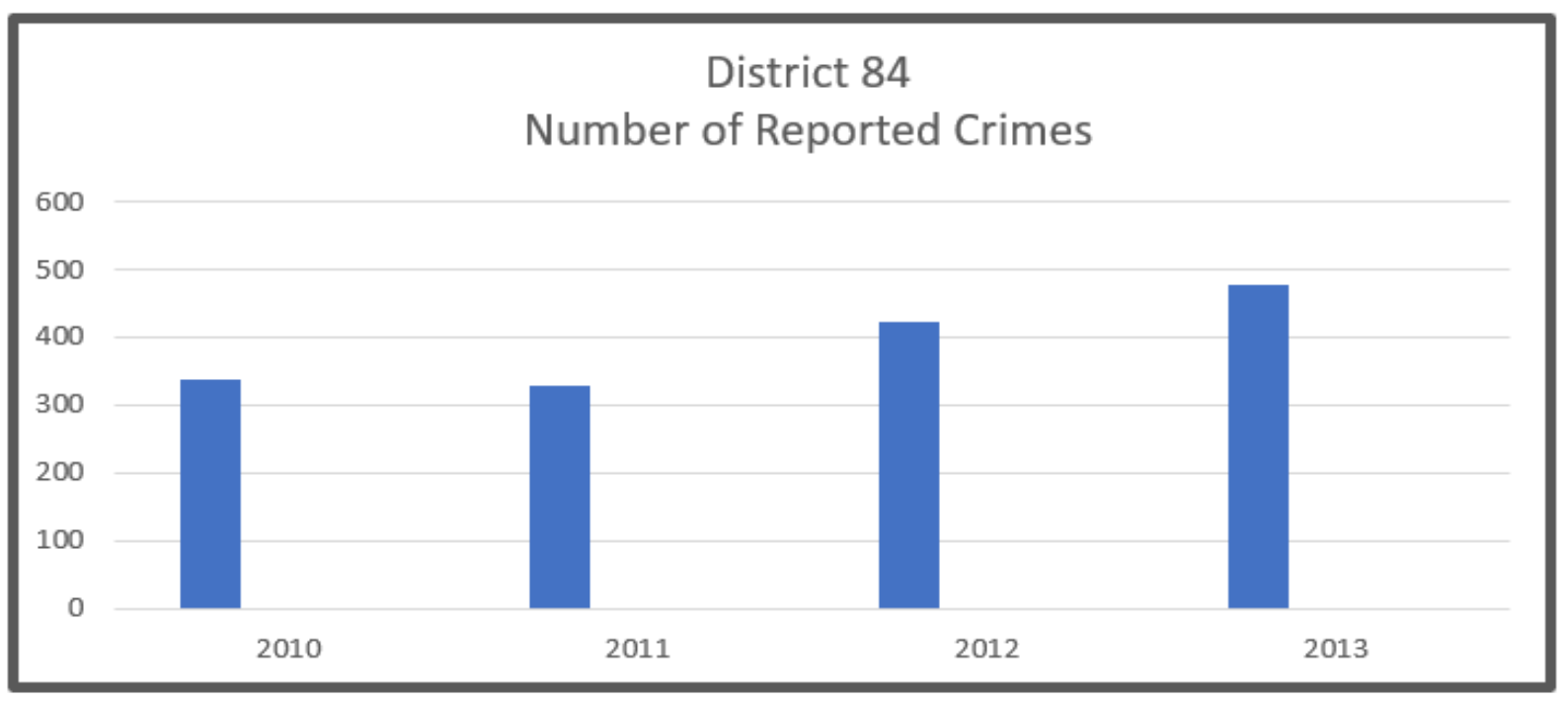

Source: Pomona Police Department

Also relevant to this study because of its direct effects on our participants and their families is the fact that, on December 18, 2017, Pomona became a so-called "sanctuary" city by

\footnotetext{
${ }^{8}$ http://www.city-data.com/crime/crime-Pomona-California.html
} 
approving an ordinance ${ }^{9}$ that ensures the implementation of California's Values Act (SB 54) ${ }^{10}$ which curtails use of state and local resources from engaging in deportations and creates safe spaces, including schools, health facilities, and courthouses.

\section{District 3}

during an interview, Pomona City Councilwoman Cristina Carrizosa explained that district 3 is predominantly Latino, immigrant, and "incredibly resilient". She claimed that many residents in her district are immigrants who arrived in the United States in the last few decades and, even though there are also second and third generation immigrant families living in the district, even when combined with U.S. born families, they are still a minority. The current constituency of District 3, informs Carrizosa, is mostly comprised of people who moved to Pomona from Los Angeles and people who migrated from Mexico, Vietnam, Cuba, and Central American countries. Most of these immigrants, according to Carrizosa, are of Mexican origin.

The residents of district 3, explained Carrizosa, are mostly blue-collar workers, with a recent emergence of college students who have moved into the area seeking the advantages of renting low-priced apartments. In discussing the subject of housing in district 3, Carrizosa said, "I believe there are too many apartments in the area. That brings problems such as crime, and sometimes just the need for additional parking." Consistent with historical research (Morales, 2016), Carrizosa explained that district 3 , which was initially slated by zoning authorities to become an industrial area, evolved into an area of apartment complexes partially in response to an increasing demand for housing after the civil unrests of 1965 (The Watts Riots) and 1992

\footnotetext{
${ }^{9}$ https://www.dailybulletin.com/2017/12/19/pomona-gives-final-approval-to-local-ordinance-ensuring-sanctuarystate-legislation-is-implemented/

${ }^{10}$ https://leginfo.legislature.ca.gov/faces/billNavClient.xhtml?bill_id=201720180SB54
} 
(The Rodney King Riots) that took place in Los Angeles. This conversion from industrial zone to multiple-family housing buildings, said Carrizosa, led to increased crime and other problems; "When you bring too many people to an area that is not designed for that...something's going to happen." (Carrizosa, 2018).

On the economic front, district 3 reported a median household income lower than the rest of Pomona. The unemployment rate reported for this district and the number of people living below the poverty level were also higher than the rest of the city (U.S. 2010 Census). When asked to comment on the differences, Carrizosa said, "I would say that there is [economic segregation in Pomona], not intended, but there is. Not intended by the governance of the city...but in a way, it's intended by the old plans that the city had [to make southern Pomona a place for industry].” Districts in south Pomona, added Carrizosa, "have been neglected for decades." Despite conditions of neglect, according to Carrizosa, the people of District 3 remain hopeful, optimistic and resilient. Citing the protests carried out by a group of approximately 600 residents against what were deemed "racist checkpoints" carried out by the Pomona Police Department in $2008^{11}$, Carrizosa highlighted the cohesion and resilience demonstrated by citizens of her district and of Pomona in general.

...the struggle against the checkpoints...that's a perfect example. It began in district 3. [I asked] the chief of police, 'why are you doing this? [Do] you realize what you're doing to this community? You're taking 400 cars per night. Look at the economic impact in a city like Pomona during recession...look at the [impact on] small businesses...even the church is not getting enough [tithes].' It was a full economic impact that nobody, nobody

\footnotetext{
${ }^{11}$ https://www.liberationnews.org/08-06-03-pomona-residents-march-against-r-html/
} 
could understand. The district suffered. Lots and lots of families left. They took their children and all of a sudden, there was no work for teachers. All of a sudden [jobs decreased]... the community became so engaged, that we fought until we controlled the checkpoints. [It was a] scary fight; full of spite and hate for our community but we fought....and won. [District 3] is an area where [once] you get to know [the] people...you get invited; you can just pop in. They celebrate in community...you see the posadas...you see the festivities of the Virgen de Guadalupe. During semana santa, you see-in connection with the [catholic] church - the Stations of the Cross. They celebrate mother's day [and] Dia de los muertos, which now is like a big party, but you know, [they celebrate] with a traditional feeling of fellowship and spirituality. People are continuing with the practices of their own hometowns... So, it's a place that, if you want to be part of it, you can be part of it...

\section{Parents' perceptions of Community}

In our quest to identify parent's perceptions of their immediate community (Table 4) and of the city of Pomona, we found that four of the five participants feel comfortable participating in city-wide events. Two of these four parents - both Mexican-have resided in the U.S. without legal documentation for five and twenty years respectively. The fifth participant, who moved to Pomona from Honduras in February of 2018, said she does not feel comfortable attending citywide events because she is afraid the U.S. Immigration and Customs Enforcement (ICE) agency will detain her, "No salimos mucho. Siempre hay temor de que te agarre la migra." (Parent E).

When asked to rate their level of comfort in expressing their opinions openly in the larger community (district or city-wide), four parents reported feeling comfortable. Two of these parents credited the mayor of Pomona and their city council representative for helping them feel 
comfortable. One of them said, "Me siento cómoda hablando con el alcalde [y con] la Sra.

Carrizosa, si queremos hacer un cambio, convocamos una junta y se invita a toda la comunidad...y somos escuchados. " 12 In addition to crediting the mayor of the city, a third parent who owns a small business in the city also credited the president of Pomona's Chamber of Commerce and a member of Pomona's school board for contributing to make her feel comfortable,

...la presidenta de la cámara de comercio... mi experiencia personal con ella ha sido muy grata. Hay una persona que si está dentro del distrito, la Dra. B. A ella también le tengo un gran respeto [porque] siempre está buscando el beneficio de los estudiantes y es parte de la mesa directiva. Hay varias personas a las que les tengo gran respeto...y que tengo toda la confianza de dirigirme a ellos. Incluyendo al alcalde de la ciudad. Alguna duda o proyecto que yo tenga, siento toda la confianza de dirigirme a él. Contrasting the views of the other four participants, the parent from Honduras expressed discomfort in sharing her views openly in the larger community and attributed this feeling to her legal status and lack of familiarity with city leaders and the city in general.

Table 4. Parent Perceptions of Community

\begin{tabular}{|c|c|c|c|c|c|}
\hline & $\begin{array}{l}\text { A } \\
\text { Pennsylvania } \\
\text { Elementary }\end{array}$ & $\begin{array}{l}\text { B } \\
\text { Pennsylvania } \\
\text { Elementary* }\end{array}$ & $\begin{array}{l}\text { C } \\
\text { Pennsylvania } \\
\text { Elementary }\end{array}$ & \begin{tabular}{l}
\multicolumn{1}{c}{ D } \\
Kentucky \\
Elementary*
\end{tabular} & \begin{tabular}{l}
\multicolumn{1}{c}{$\mathbf{E}$} \\
Kentucky \\
Elementary*
\end{tabular} \\
\hline $\begin{array}{l}\text { Leaders in my } \\
\text { community kmow } \\
\text { and respect my } \\
\text { family's culture }\end{array}$ & Yes & Yes & Yes & No & No \\
\hline $\begin{array}{l}\text { Community is a } \\
\text { space where I and } \\
\text { other immigrants } \\
\text { can express views } \\
\text { without rear }\end{array}$ & Yes & Yes & Yes & Yes & No \\
\hline $\begin{array}{l}\text { Feel comfortable } \\
\text { participating in } \\
\text { community-vide } \\
\text { events }\end{array}$ & Yes & Yes & Yes & Yes & No \\
\hline $\begin{array}{l}\text { There is at least } \\
\text { one community } \\
\text { leader I can } \\
\text { approach with } \\
\text { concerns }\end{array}$ & Yes & No & Yes & Yes & No \\
\hline
\end{tabular}

12 "I feel comfortable talking to the Mayor and to Mrs. Carrizosa, if we want to enact change, we call for a meeting and the entire community is invited... and we are listened to." 


\section{Pennsylvania Elementary}

Pennsylvania Elementary School (PES) is located in reporting district 84 in the city of Pomona. As of the end of the 2016-2017 school year, according to a school profile published by the California Department of Education, Pennsylvania enrolled 662 students; of which 93.4\% received free/reduced lunch and $42.6 \%$ were identified as English Language Learners (ELs). Of the 289 students identified as ELs, $98.6 \%$ came from homes where Spanish was the primary language. $94.9 \%$ of the entire PES student population is considered by the state of California to be socioeconomically disadvantaged (California Department of Education, 2017).

The Principal of PES identifies as Latinx and is fully bilingual (Spanish and English). According to a local source, the staff (i.e., administrators, teachers, paraprofessional, administrative personnel, etc.) at PES is 61\% Latinx, 26\% Caucasian, $11 \%$ Asian, and 2\% African American.

When asked to comment on the constituency of PES during separate interviews, one of the participants and the Principal of the school used the term "tight-knit" to describe it. The Principal, who has worked at PES for seven years and whose own daughter also attended Pennsylvania Elementary, said, "I have to say, the makeup of the community here is very, very tight-knit. They're a very tight-knit group. And, I'm talking about teachers as well as the parents and community; they're very protective of this school. And they're very protective of our students." Echoing the words of the principal, a PES participant who is actively involved in the school's Parent Teacher Association (PTA) and in two other school committees added, “[Estamos] unidos...nos preocupamos por nuestros niños, por nuestros jóvenes. Queremos que 
tengan un ambiente seguro, un ambiente libre de drogas, y pues estamos luchando juntos por eso."

When asked to talk about the school's attitude toward parents—citing the principal's knowledge and respect for their culture, her willingness to listen, and her demonstrated commitment to answering their questions promptly and politely —all three PES participants reported feeling welcome and comfortable participating in school-related events.

\section{Kentucky Elementary}

Kentucky Elementary School (KES) is located in the southeastern part of Pomona. During the 2016-2017 school year, according to the California Department of Education, KES enrolled 637 students; of which $93.7 \%$ received free/reduced lunch and $34.7 \%$ were identified as English Language Learners (ELs). Of the 221 students identified as ELs, $97.18 \%$ came from homes where Spanish was the primary language. $94 \%$ of the entire KES student population is considered by the state of California to be socioeconomically disadvantaged. The principal of KES identifies as Latinx and speaks Spanish.

Reflecting on her experiences at KES, Linda, whose child has been enrolled at KES for 3 years said that, while she feels comfortable participating in school-related events and activities, she does not believe the school is very welcoming to parents in general and that only parents who volunteer or participate in committees are acknowledged and respected.

Yo, en mi caso personal...lo que he visto que me abrió puertas más, es cuando empecé a involucrarme en los comités... El participar en un comité; como ser presidenta [del comité] de niños aprendices de inglés, ahora veo la amabilidad.... [me] reconocen en la dirección 
de la escuela...la directora [dice], "Hola, como esta señora?" Al menos saben [mi] apellido. Pero veo la diferencia. Si uno no participa y se involucra, es una mamá más.

Citing occasions when members of the school's personnel were rude to her and to other parents, Linda credited her feeling comfortable at KES, not to the efforts of the principal or other members of the school's staff, but rather to her association with other parents and to her involvement with Padres Unidos de Pomona, a community organization composed of parents and community members from Pomona who organize throughout the community to advocate for the rights of students and parents. ${ }^{13}$

A review of KES' website revealed that, while the school offers a variety of language choices to navigate their webpage, the Parent Portal - the means by which parents are able and expected to connect with teachers and other school personnel—is available only in English; something that represents a barrier for parents with limited or no knowledge of the English language. When asked to comment and evaluate KES' communication efforts as it pertains to parents with limited or no knowledge of the English language, Linda stated that the process of communication is further complicated by the lack of proficiency in Spanish of school personnel and by parents' limited abilities to effectively utilize digital navigational tools. In support of her claim, Linda cited the following quote from a letter she received from her son's school principal at the beginning of the year:

Los estudiantes de ["Kentucky"] recibirán instrucción de alta calidad como parte de un programa académico riguroso e integral. A través de la enseñanza de los Estándares Comunes aprenderán a colaborar, efectivamente comunicarse verbalmente y por escrito,

\footnotetext{
${ }^{13} \mathrm{https} / / /$ www.genteorganizada.org/pomona-parents-union
} 
pensar críticamente, y desarrollar confianza en sus habilidades. El programa educativo de la escuela incluye estrategias de AVID, Cuestionamiento Basado en Documentos, RESPECT-Lecciones de Ciencias, ELD Sistemático, además que también hay un gran enfoque en la tecnología. Como parte de la cultura académica de la escuela pedimos que los alumnos usen sus camisetas de Tigres a diario.

In her critique of the letter, Linda — who completed high school in Mexico and is fully fluent in Spanish—said that in addition to being unclearly written, the translation wrongly assumes that all readers are familiar with the programs and their respective acronyms. As an example of what she called "literal and ininteligible" phrases, she quoted the following, " $E l$ programa educativo de la escuela incluye estrategias de AVID, Cuestionamiento Basado en Documentos, RESPECT-Lecciones de Ciencias, ELD Sistemático, además que también hay un gran enfoque en la tecnología. " In summarizing her critique of the language used by the principal in her letter, Linda expressed frustration and confusion stating that this type of flawed communication not only makes it difficult for her and other Latinx immigrant parents to understand the message the school is trying to convey, but also makes it hard to believe that schools are serious about improving their communication with them. Linda concluded saying, "Cuando uno ve esto...es difícil creer que las escuelas realmente nos toman en serio..." In the same vein, Blanca, our Honduran participant, whose two children have been enrolled at KES since March of 2018, offered her thoughts about KES' attitude toward immigrant parents and its knowledge and understanding of her family's culture, "Siempre creen que todos somos mexicanos... hay gentes [sic] que ni siquiera saben dónde queda mi país. Somos latinos, pero no todo es igual... hay diferencias... diferentes modos de ser y de vivir..." Recognizing that KES makes an effort—albeit superficial in her opinion — to be welcoming to 
parents, Blanca claimed that the school's personnel does not take sufficient steps to get to know her and her family's culture.

Parents' perceptions of Schools

In gauging the perceptions parents hold of their children's schools (Table 5), we discovered that all five participants believe it is important for school personnel to be familiar with their respective cultures. Sofia, a parent from Kentucky Elementary, emphasized the importance of cultural competency in parent engagement giving an example, "Claro, por supuesto! Tiene mucho que ver la cultura. En nuestros países...en México, específicamente, los padres van y llevan a sus hijos...y los maestros se encargan de la educación." Sofia went on to explain that culturally, Mexican parents are accustomed to yield power to teachers and administrators and that they do not perceive themselves with sufficient power to influence their children's schools or to guide their educational trajectory. Sofía elaborated, “Aquí, en la parte teórica, es más abierta la escuela. Pero no todos los padres lo saben. Y vuelvo, la parte cultural se continúa: es la no involucración.” According to Sofia, even though schools are generally more inclusive of parents in the U.S. than they are in Mexico, parents do not know this and the tendency toward disengagement continues.

When asked if they believe the personnel in their children's schools knows and understands their culture, three of the five participants (all Mexican) said they believe the principals and teachers at their children's schools make serious efforts to get to know and understand their cultures. The other two participants - one of them being Blanca, the mother who recently migrated from Honduras — said they do not believe schools understand their family's culture. 
With the exception of Blanca, the remaining participants said there is at least one person at their children's school with whom they feel personally connected and that makes them feel comfortable to ask questions related to their children's education; of these four parents, two named the principal of the school, one named her child's teacher, and the fourth named the school's translator (paraprofessional). Blanca attributed her lack of connections to her not knowing the English language and her short time living in the U.S.

When prompted to share their thoughts about their children's schools, four participants reported feeling comfortable asking questions and making suggestions at their children's school. Concurrently, all five participants reported feeling welcome and comfortable participating in school events. Commenting on the attitudes of school personnel, all participants agreed that the staff in their children's schools makes efforts to help them feel welcome and comfortable. The words amable and atentas were used by four of the five participants to describe the attitudes of the school personnel with whom they interact. When asked to share the rationale behind their evaluation of the school personnel, parents cited the ability and willingness of teachers and administrators to listen to them and to answer their questions promptly and politely. In referring specifically to the administrators at their respective schools, parents also attributed their approval to the fact that principals are bilingual and that they make them feel like their opinions matter.

Table 5. Parent Perceptions of Schools

\begin{tabular}{|c|c|c|c|c|c|}
\hline & $\begin{array}{l}\text { A } \\
\text { Pennsylvania } \\
\text { Elementary }\end{array}$ & $\begin{array}{l}\text { B* } \\
\text { Pennsylvania } \\
\text { Elementary }\end{array}$ & $\begin{array}{l}\text { C } \\
\text { Pennsylvania } \\
\text { Elementary }\end{array}$ & \begin{tabular}{l}
\multicolumn{1}{c}{$\mathbf{D} *$} \\
Kentucky \\
Elementary
\end{tabular} & \begin{tabular}{l}
\multicolumn{1}{c}{ E* } \\
Kentucky \\
Elementary
\end{tabular} \\
\hline $\begin{array}{l}\text { The school knows } \\
\text { and respects my } \\
\text { family's culture }\end{array}$ & Yes & Yes & Yes & No & No \\
\hline $\begin{array}{l}\text { School makes an } \\
\text { effort to make me } \\
\text { feel welcome }\end{array}$ & Yes & Yes & Yes & Yes & Yes \\
\hline $\begin{array}{l}\text { I feel comfortable } \\
\text { participating in } \\
\text { school events. }\end{array}$ & Yes & Yes & Yes & Yes & No \\
\hline $\begin{array}{l}\text { There is at least } \\
\text { one member of the } \\
\text { school's stafi with } \\
\text { whom I feel } \\
\text { personally } \\
\text { connected }\end{array}$ & Yes & Yes & Yes & Yes & No \\
\hline $\begin{array}{l}\text { I feel comfortable } \\
\text { asking questions } \\
\text { and making } \\
\text { suggestions at my } \\
\text { child's selool }\end{array}$ & Yes & Yes & Yes & Yes & No \\
\hline
\end{tabular}




\section{Major Themes: Results and Findings}

Three key themes emerged from the in-depth, semi-structured interviews of Latinx immigrant parents sharing the experiences and perceptions that shape their willingness to become involved at their children's school. These themes are: 1) Influence of legal status and level of acculturation on parent experiences; 2) Influence of interactions - both with school personnel and community leaders_on parents' perceptions; and 3) Effects of State and city policies on parent's perceptions, experiences, and willingness to become involved. (Figure 1)

Figure 1. Factors determining parent involvement

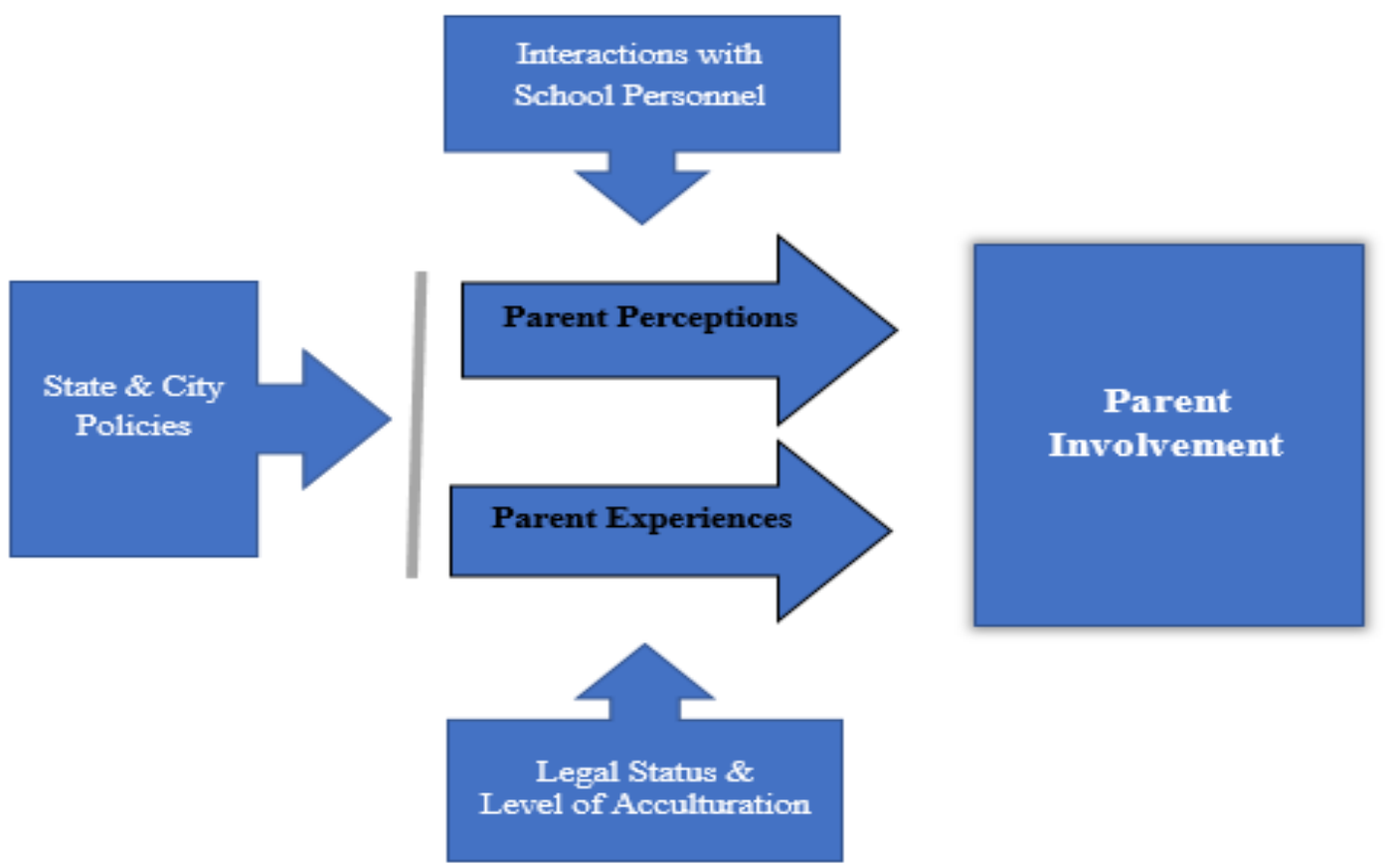

\section{Legal Status \& level of acculturation}

In analyzing the results of our study, we found that legal status and level of acculturation play a pivotal role in parent involvement. Not surprisingly, our study found that parents who 
reside legally in the U.S. are more active in participating in events at their children's schools than their counterparts without legal status. Not accounting for levels of education and acculturation, we highlight that parent C, who has resided legally in the U.S. for 22 years, reported an average of 24.25 visits per semester, while parents without legal status (B \& D) reported averages of 10.5 and 9.5 respectively. It is important to note that parents $\mathrm{A}$ and $\mathrm{E}$ were not included in this comparison because of insufficient data. Parent A assumed custody of her two grandchildren less than 2 years ago and parent $E$ has only lived in the U.S. for eight months.

Coincidently, when asked if they understood the differences between local (city and state) and federal immigration laws, parent $\mathrm{C}$ was the only one to respond with absolute certainty stating that the most unfavorable policies for immigrants arise at the federal level and that immigrants enjoy a certain level of protection in California.

Yo creo que los cambios más fuertes son los federales, porque...California lo dejo saber desde un inicio: somos un estado de inmigrantes. Entonces, [los gobernantes] hicieron saber públicamente...que no estaban interesados en la persecución del inmigrante. Entonces yo creo que, aunque hay de todo... los cambios desfavorables hacia el inmigrante, yo creo que se dan más a nivel federal que estatal. Igualmente...el alcalde [de Pomona] también lo hizo saber: no hay persecución para el inmigrante en esta ciudad. Entonces se cuenta con esa amplitud y una cierta protección para el inmigrante. Although with less certainty, the remaining four participants demonstrated awareness of differences between local and federal immigration policies, but were not exactly sure of what those differences were. All five participants, however, expressed feeling safe living in California and described it as an "immigrant friendly" state. Linda, who moved to Pomona from Texas in 
2013, was particularly keen in pointing out that, other factors notwithstanding, she felt safer living in California than she did in Texas.

In further analyzing the factors that influence parents' experiences, we noticed that parents with higher levels of acculturation - as demonstrated by their knowledge of the English language, their understanding of school cultures (Delpit, 1988), the curriculum and organization of U.S. schools, and of their rights as parents (Delgado-Gaitan, 1990)—regardless of their legal status, were more likely to become involved in their children's schools. Linda, for instance, who has lived in the U.S. without legal documents for 20 years (15 years in Texas and 5 years in California) and who is vice-president of the English Learner Advisory Committee (ELAC) at her daughter's school and member of three other committees at the school district level, reported the second highest average of visits to her children's school. When asked to elaborate on the factors that motivate her to become informed about the school system and to be more actively involved at her child's school in spite of her legal status, Linda credited the positive interactions she has had with school personnel, community leaders, and with other parents in her community. Her participation in the community organization Padres Unidos de Pomona (PUdeP) and her close relationship with the parents of her dance troupe, claims Linda, helped her acculturate and adapt to her new environment; all of which had significant impact on her decision to become actively involved in her daughters' schools.

Llegamos [de Texas] el 2013 y ni siquiera sabía o entendía que era un niño aprendiz de inglés y estaba ajena a todo. No sabía ni como poder ayudar a mis hijas para reclasificar. En primer lugar, el primer crédito es para ese grupo [PUdeP] donde me decidí involucrar... eso fue lo me abrió mis primeros pasos... Y también, pues el distrito, lo que he aprendido en el distrito. Las juntas de padres líderes que hacen en el distrito... 
una vez al mes...es la motivación...que quiero ir a la junta porque me van a dar un certificado...y eso me ayudo a ser como yo lo veo, a ser como brazos de árbol... [Los padres van] al distrito y aunque no seamos de la misma escuela...nos conectamos y nos ayudamos unos a otros... ahí, como ejemplo es el bailable: no todas éramos de la misma escuela y sin embargo, el bailable nos unió. Empezamos a bailar...me integré al grupo folklórico y también eso me abrió otras puertas, otros brazos. Antes...sentía miedo hasta de levantar la mano. [Tenía miedo] que no se tomara en cuenta mi opinión...que no les interesara mi punto de vista... ahora ya no. Eso me ayudó a darme cuenta que mis hijas tienen derechos. Yo soy su abogado. Yo soy su voz.

Thus, as evidenced by the number of visits to their children's schools and their active involvement in school affairs both at the school and district levels, it can be deduced that parents who have amassed higher levels of acculturation through their experiences—regardless of legal status-are more likely to become involved.

\section{Interactions}

\section{Interactions with school personnel}

A second theme that emerged in the course of this study was the role of interactions. In listening to our participants, we discovered that the perceptions they hold of their children's schools and communities are greatly influenced by the quality of the interactions they have with school personnel and, to a lesser degree, with community leaders. Interactions with school personnel listed by participants range from casual interactions with office personnel to meetings with teachers and with the principal. The interactions with community leaders-in particular with Pomona's mayor and a city council representative-were occasional and occurred mostly during open community events such as town hall meetings and monthly community clean-ups. 
The most common forms of interaction cited by parents with their children's school staff were parent-teacher conferences and the monthly "Coffee with the Principal" meeting. Three parents also cited interaction with school personnel during training workshops both at the school and at the offices of the Pomona Unified School District.

Using data gathered from parents (Table 6), we found that parents who felt respected and welcome, and who had at least one meaningful personal connection with a member of the school's staff (Table 4), were more likely to participate in school events. An example of this were participants A, B, and C from Pennsylvania Elementary, who collectively reported a higher number of visits to their children's schools than parents D and E from Kentucky Elementary School, who coincidently reported not feeling respected by their school and not having personal connections with anyone in the school's staff.

Table 6. Average visits to school per semester

\begin{tabular}{|c|c|c|c|c|c|}
\hline & $\begin{array}{c}\mathbf{A} \\
\text { Pennsylvania } \\
\text { Elementary }\end{array}$ & $\begin{array}{c}\mathbf{B}^{*} \\
\text { Pennsylvania } \\
\text { Elementary }\end{array}$ & $\begin{array}{c}\mathbf{C} \\
\text { Pennsylvania } \\
\text { Elementary }\end{array}$ & $\begin{array}{c}\mathbf{D}^{*} \\
\text { Kentucky } \\
\text { Elementary }\end{array}$ & $\begin{array}{c}\mathbf{E} \\
\text { Kentucky } \\
\text { Elementary }\end{array}$ \\
\hline $\mathbf{2 0 1 8}$ & 14 & 20 & 22 & 3 & 1 \\
\hline $\mathbf{2 0 1 7}$ & 5 & 12 & 35 & 10 & N/A \\
\hline $\mathbf{2 0 1 6}$ & N/A & 10 & 20 & 15 & N/A \\
\hline $\mathbf{2 0 1 5}$ & NA & N/A & 20 & 10 & N/A \\
\hline $\begin{array}{c}\text { Average } \\
\text { Visits per } \\
\text { Semester }\end{array}$ & 4.75 & 10.5 & 24.25 & 9.5 & .25 \\
\hline
\end{tabular}

Commenting on the factors that motivate them to become more involved, parents named the efforts of school personnel to make them feel welcome and comfortable while visiting the school. Parents also mentioned the ability and willingness of the principal and other school staff to listen and to address parent concerns promptly and politely. Elaborating on the subject, one of the parents at Pennsylvania Elementary said, 
Me gusta participar en la escuela porque siento que sí nos escuchan...el personal de la oficina siempre me ha atendido muy bien; [son] muy atentas las secretarias y el personal administrativo. La directora siempre está escuchándonos...si la invitamos a alguna convivencia viene...es muy humilde. Nos hace sentir cómodas porque nos habla en español...y [porque] siempre está dispuesta a escucharnos...aun cuando está muy ocupada...nos dice 'si ocupan algo, vayan a la oficina' y hacemos cita y nos atiende. Also commenting on factors that influence her decisions to become involved at her child's school, parent D from Kentucky Elementary mentioned that even though the principal of the school and some teachers make personal efforts to make her and other parents feel welcome at the school by greeting them politely and speaking Spanish to them, the rest of the staff is not as welcoming. In illustrating her point, she offered the following about the lack of professionalism she has encountered at her daughter's school.

Cuando recién llegué [de México] ...llegaba a la oficina a hacerles preguntas, pero ni siquiera el saludo me contestaban. Yo pienso que no son profesionales...están en el trabajo nomas por ganarse un sueldo. No les gusta su trabajo...tan solo desde la oficina, el personal que está en frente...es importante su actitud...porque hay papás y mamás que tienen hasta miedo de ir a la oficina a preguntar.

\section{Interactions with community leaders}

As mentioned above, in addition to the interactions parents have with school personnel, we also found that the interactions parents have with community leaders—albeit sporadic —also play a role in the development of parent perceptions. In gauging the perceptions parents hold of their community (Table 4), we asked them a few questions about leaders in their community. When asked if they believe their community leaders know and understand their culture, three of 
the five participants said they believe community leaders know and respect their cultures. In sustaining her claim that community leaders know and understand her family's culture, and echoing the opinions presented by two other participants, participant $\mathrm{C}$ mentioned the diversity that is present in the city's leadership and the Mexican background of Pomona's mayor, "Hay personas de diferentes partes del mundo en la mesa directiva del distrito y del concilio de la ciudad...El alcalde, por ejemplo, [dice] 'mis papas son de descendencia Mexicana ...yo quiero ayudar a mi gente, a mi comunidad." The remaining two participants declined to answer the question stating they had little or no contact with community leaders.

Likewise, when questioned about their level of comfort in expressing their opinions and concerns about their community, four parents - two of them residing in the U.S. without legal documentation — said they feel comfortable approaching community leaders to address community issues. One of the parents who is actively involved in her school's PTA and in other committees said, “...creo que si existe la libertad de que la gente opine. He estado en juntas en el distrito escolar ... y uno puede expresarse. Igual en las juntas del city hall, también hay gente que expresa libremente lo que quiere decir. Yo lo he hecho en varias ocasiones." Contrasting the responses of her fellow participants, participant E offered, "Creo que algunas personas si lo hacen ...como los que tienen papeles (de inmigración) o que hablan inglés. Yo no [me siento cómoda expresando mis ideas]. Estamos aquí sin papeles ... y cualquier cosita nos puede meter en problemas... asi es que mejor no.”

With the exception of parent $\mathrm{E}$, the other four participants said there is at least one community leader with whom they feel personally connected and that makes them feel comfortable to share their opinions and concerns. Of the four parents responding affirmatively, two mentioned City Council Member Cristina Carrizosa and the other two named the Mayor of Pomona as 
community leaders with whom they have a personal connection. In justifying their opinions, these parents mentioned the ability of both leaders to communicate with them in Spanish, their respectful and professional demeanor, and their willingness to listen. Additionally, participants who claimed having meaningful relationships with community leaders cited pleasant interactions, genuine interest in the wellbeing of the community, trust, and responsiveness as factors that contribute to the creation of such relationships.

In an effort to triangulate our findings, we asked the Principal of Pennsylvania Elementary to review and evaluate the average of visits our participants make to their children's schools. Upon careful analysis, she informed us, based on her seven years of experience as principal at PES, that the numbers our participants report are unusually high. She estimates the average parent visits his/her child's school 2-4 times per semester. Hence, we found that the parents in our study who feel respected and safe both in their children's schools and communities, and who have at least one meaningful personal connection with a community leader are more likely to partake in school events.

\section{State and City Policies}

In analyzing the role that local (school and city) and regional (state) policies play in Latinx parent involvement in Pomona, we discovered a linear relationship: state policies influence local policies and local policies, in turn, influence School district policies that manifest into school cultures that have a direct influence on parent involvement. (Figure 2) 


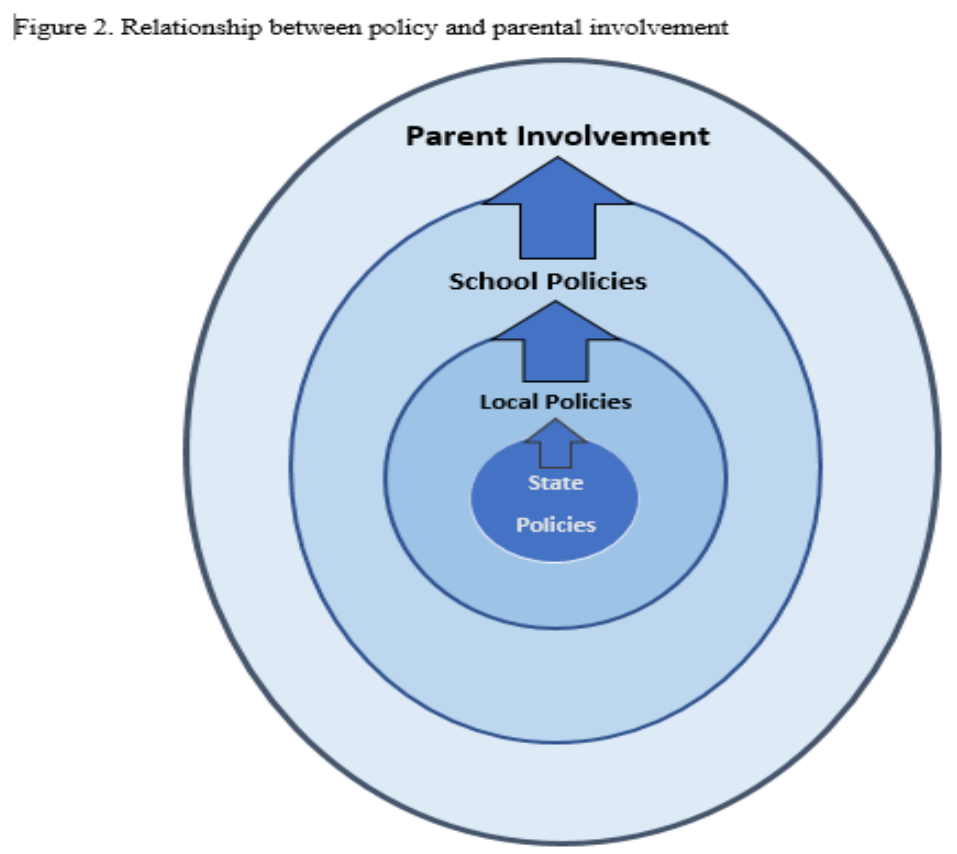

At the state level, in 2017, and not without controversy, California passed a law that limits the ability of law enforcement agencies to work with federal immigration agencies to detain and investigate people on the basis of immigration purposes. Senate Bill 54 (SB 54) or the California Values Act, as this law is known, prohibits the detention or holding of undocumented individuals who have not been convicted and precludes state and local law enforcement from using financial resources or personnel to "investigate, interrogate, detain, detect, or arrest persons for immigration enforcement purposes." ${ }^{14}$ Under this bill, police agencies and staff working for them are limited to no longer inquire information regarding a person's legal status, release private information that is not yet available to the public, or detain and question amongst other things on the basis of aiding an immigration enforcement agency/investigation.

\footnotetext{
${ }^{14}$ https://leginfo.legislature.ca.gov/faces/billTextClient.xhtml?bill_id=201720180SB54
} 
SB 54 directly affects k-12 schools under local governing in that it includes regulations that prevent immigration agencies from working in school campuses and from having individuals transferred to them without a judicial warrant. The bill requires public schools to follow the policy, or to create their own that is up to par with the one created by the Attorney General. Because of its implications, SB 54 has been perceived by some as California's biggest step toward turning the state into a "sanctuary state."

As stated above, in keeping with state policy, after a series of heated debates that included supporters and opponents of SB 54, the city council of Pomona unanimously approved an ordinance that upholds the California Values Act and that, according to Councilwoman Ginna Escobar, addresses the needs of residents who live in fear.

In the same manner, and following the lead of both state and city leaders, the directives of Pomona Unified School District adopted and implemented policies that guarantee the safety of students and parents while they are on school campuses. In discussing the subject, the principal of Pennsylvania Elementary assured that school officials have done "everything in their power" to make sure immigrant parents feel safe. Of her own efforts at Pennsylvania Elementary, the principal said, "When I did 'Coffee with the Principal', I eased them (parents)...it took a while because they had this fear (of being detained and deported)...it was hard work, but we did it!"

Thus, in studying the effect regional and local immigration policies have on parents' perceptions and experiences, we found that, even when not totally sure about the differences between federal and state laws, all participants reported feeling safe living in California because they deem it "un estado de inmigrantes" that protects them.

Admitting deep concern about the election of an openly anti-immigrant president, when asked if the changes in federal immigration policy from the past three years had affected their 
willingness to remain or become more involved at their children's schools, three parents admitted feeling uneasy and afraid for the first few months. The remaining two reported not being personally affected, but deeply concerned for the future of undocumented families in their community. Subsequently, all parents reported going back to their normal patterns of involvement at their children's schools. In justifying her reply, Parent C gave examples of how the leadership both of the city and of PUSD demonstrated its support for immigrant families making them feel safer.

Al principio si hubo mucho temor por [parte de] padres que sabían que de alguna forma iban a estar afectados. Pero también el distrito escolar hizo mucho hincapié de que se le iba a dar la protección necesaria a los estudiantes. En diversas juntas...por ejemplo, la policía no podía entrar a la escuela a buscar estudiantes. Se hicieron talleres para los padres que decidieran retirarse del país y que hicieran [sic] la doble ciudadanía para sus hijos; para que ellos pudieran estudiar en México o en cualquier otro país que tuviera la doble ciudadanía. Se llenaron las formas en caso de que los...padres quisieran dejar los niños aquí. Se hizo el workshop/taller de como llenar las formas adecuadas para darle la tutoría a alguien más en lo que se resolvía la situación legal. Si hubo apoyo por parte de la ciudad y del distrito [escolar] en ese aspecto. [Mi disposición para involucrame] no ha cambiado.

Concurrent with the responses of our participants, the principal of PES said that although parent involvement decreased significantly at her school after the presidential elections of 2016, it has slowly been rising and nearing what it was prior to the elections. 
[After the election of the new president] we started to see less of our parents. With the new administration... I noticed more people not coming as often, but I think it was for fear... When [the new president] was elected, we had students that were crying here because they [thought] their families were going to be deported. So, it was a really hard day for everyone here because we had so many students that had this fear that [their] families were going to be taken away. And so, I think that caused a little less [parent involvement] because parents were afraid... [Parents] would say, 'If I come here, I have to show my ID and if I don't show my ID, someone's gonna [sic] know that I'm not legal and then someone will report me.' And that's when distrust came and we had to talk to them... We do our best to talk to them and many have come back...

Hence, the implementation of what could be viewed as immigrant-friendly policies at PUSD, the city of Pomona, and the state of California has-at least in the communities involved in this study — contributed to create cultures of trust where immigrant parents, regardless of their legal status, feel safe and comfortable becoming involved at their children's schools. 


\section{Chapter 5: Discussion and Conclusions}

As trends in EL enrollment are predicted to remain steady in the State of California and elsewhere in the U.S., attention to the particular needs of the EL population is warranted. This study examined the experiences and perceptions of Latinx immigrant parents and the ways in which these affect their ability and/or willingness to engage with their children's schools. Latina immigrant parents and school and community leaders were included in this research as a means of offering perspective on the impact anti-immigrant policies have had on parent involvement since 2015 .

This final chapter summarizes the results from this research study. It also provides a discussion of the main findings related to the question of how the experiences and perceptions of parents have influenced their disposition to become involved in their children's schools. A section on the implications of the findings along with recommendations for practice and future research will follow in the proceeding sections.

\section{Summary of findings}

Concurrent with other studies, this study found that Latinx immigrant parents who reside legally in the U.S. and those who possess high levels of acculturation experience school and community environments more positively and are more likely to interact with their children's schools more frequently. We also found that positive interactions with school personnel, community leaders, and with other parents contribute to shape cultures of trust in the parents' minds. In the same vein, we discovered that regional and local policies that address the needs of residents who live in fear (i.e., undocumented immigrants) influence parents' perceptions by making them feel safe and protected not just within schools, but also within their communities. Collectively, as found by this study, legal status and acculturation, along with interactions and 
policies, have great influence on the level of confidence parents develop to actively engage with their children's schools.

In addressing the question of how parents in our study perceive the respective cultures of their children's schools and communities, we discovered that, despite living in conditions of oftentimes extreme poverty and violence, the majority of the participants perceive their community as being a safe and welcoming place for immigrants. Community engagement, as defined both by parents and community leaders, is "tight-knit" and multifaceted. People in district 3, according to Councilwoman Carrizosa, engage meaningfully with each other and with city leaders in ways that are both personal and collective.

Community engagement, there's no single way that you can define it because the community has different interests and they engage in different ways. [People] engage...in more ways than we can imagine. They engage among themselves in such a way that, if there's a need... when somebody dies... the community gather[s] together; do[ing] car washes, cooking, you name it...[to] come up with the money to pay for the [funeral expenses]. And...within the schools, many principals are very good community leaders and are able to engage the parents. Here, at city hall, I have seen the community engage in so many ways. There have been times when there's not enough room for all the community because hundreds come. The change that I have seen through the years is that the community feels very, very comfortable.

Along the same lines, when asked to describe the constituency of Pennsylvania Elementary, giving specific examples, the principal explained that even when PES faces serious problems like underfunding, homelessness, and violence, the people in the community remain solidary and optimistic. 
When I was first at PES, many people told me, 'oh, you need to be very on guard with that school. That school's a bad school. The students, the families are terrible.' [But] I have to say, the makeup of the community here is very, very tight-knit. They're a very tight-knit group. And, I'm talking about teachers as well as the parents and community; they're very protective of this school. And they're very protective of our students. I don't know how many times we get phone calls from parents say[ing], 'you know, we see a suspicious person...we're gonna call the police, but we just wanna let you know.' They're very protective of what happens here. We always keep the lines of communication open at all times and I think they (parents) feel that sense of community and love!

Echoing the words of councilwoman Carrizosa and of the principal of PES, Parent E (from Kentucky Elementary), who has lived in Pomona for eight months, said that although she was "very scared" when she first moved to the U.S., her fears were greatly eased by her interactions with two community members whom she met at church; one is an active community organizer and the second an employee of the city of Pomona. "People around here are nice," explained Blanca, "they make me feel welcome and less afraid." Likewise, parent D (also from Kentucky Elementary) who is in the process of legalizing her residential status in the U.S., credited her increased self-confidence and sense of belonging to the members of her dance troupe who reached out to her and have been supportive of her and her daughters since she moved to California in 2013.

In discussing the way in which perceptions affect parents' decisions to engage with their children's schools, we would like to point out that the levels of involvement demonstrated by the participants of this study were unusually high when compared to other parents in general 
(Castaneda, 2018). Based on data (tables $3 \& 4$ ), we attribute the high levels of participation to the fact that all parents, regardless of legal status, feel respected and welcome at their children's schools and in their communities. As shown by the data, parents have established meaningful relationships with school and community leaders through constant, positive interactions where the leaders have demonstrated genuine interest in the wellbeing of all children and of the community in general.

In schools, parents feel comfortable asking questions and making suggestions because they can communicate with the principal and other school staff in Spanish. The ability and willingness of teachers and administrators to listen to them and to answer their questions promptly and politely encourages them to become more actively involved.

At the community level, parents feel represented and safe. They believe their neighbors and people like the Mayor of Pomona and their city council representative (who are both bilingual and members of immigrant families) really understand their life conditions and have their best interest at heart.

Perhaps the question of how parents in our study make their decisions to become involved at their children's schools can be best addressed using the words of parent D who emphasized the importance of trust and genuine interest on the part of schools.

La vida es dura para todos...pero especialmente para nosotros los inmigrantes...hacemos la lucha...por aprender inglés y las cosas de este país...pero eso siempre lleva tiempo. Necesitamos mucha paciencia...porque sí podemos...yo creo que con paciencia todo se puede. Así es que cuando nos encontramos con gente que de verdad nos inspira confianza y que de verdad se preocupa por nuestras familias... hacemos todo lo posible por trabajar con ellos. ¡Damos el cien por ciento! 


\section{Conclusion}

The study set out to explore the experiences and perceptions of Latinx immigrant parents and the ways in which these affect their willingness to engage with their children's schools during "contested times." Addressing the urgent need to survey the current context of immigrant families and responding to a call for studies that approach the problem of low parent involvement in schools from an asset-based perspective, this study sought to learn directly from Latinx immigrant parents to what extent the implementation of anti-immigrant policies has affected their willingness to become involved in their children's schools. More specifically, the study sought to find out how parents perceive the cultures of their children's schools and how these perceptions affect their decisions to engage with their children's schools.

After a thorough analysis of the data presented by the five participants in this study, it became evident that legal status, level of acculturation, and regional policies play a decisive role in parents' choices. Furthermore, we discovered that parent perceptions and experiences are greatly influenced by their interactions with school personnel, community leaders, and with each other. While the influence of interactions with school personnel and community leaders was anticipated from the beginning of this study, the latter; the influence of interactions with other parents, was something we had not encountered in the literature and completely novel to us. Without exception, all the participants pointed to interactions with other parents in their community as playing an important role in their decision to become more actively involved in their children's schools.

The completion of this study yielded a clear conclusion that much needs to be done to effectively engage Latinx immigrant parents and to increase their involvement at their children's 
schools. From theory to practice, there is much of what we think we know and accept as fact about Latinx immigrant parents that needs to be revisited and modified.

Schools need to understand that while Latinx parents come to them with unequal resources and with complex identities and family history dynamics, they also come with unique and powerful assets. Subsequently, recognizing the existence of alternative forms of capital in minoritized communities, schools must reimagine their perceptions of and interactions with such communities. This process of transformation must, by necessity, begin with an explicit understanding on the part of institutions of important general cultural characteristics of Latinx immigrant communities. As sociologists of immigration have noted, Latinx immigrant parents are generally optimistic and determined. As demonstrated by this study, despite legal status and/or adverse socioeconomic factors, these parents show a strong sense of solidarity and resiliency that serve as powerful counterforces that help them to not only survive, but also to thrive. These characteristics or "personal resources", when systematically acknowledged as assets and fostered, can be utilized to create more culturally responsive, effective educational systems capable of transforming school cultures that can lead to greater academic achievement among Latinx ELs and other minoritized students.

Thus, in the process of recognizing the assets already present in underrepresented communities, it becomes imperative to walk away from attitudes and practices that operate on preconceived notions and deficit approaches. Rather than focusing on the weaknesses or deficits of these communities, plans and projects wanting to support and improve conditions for minoritized groups must actively seek to become familiar with the unique circumstances of each learning community and the alternative forms of capital diverse families bring to the table and- 
in direct, genuine collaboration with the people they claim to serve-find ways to incorporate the information gathered into the problem-solving process.

The schools in our study, for example, would greatly benefit from acknowledging the potential power of peer support. As demonstrated by the experiences of our participants, parents tend to trust each other and have the ability to provide one another with support that can lead to greater levels of acculturation and an increased sense of self-efficacy; both of which have proven conducive to greater school involvement.

Acknowledging the study's briefness and relatively small size of our sample as factors that limit our ability to draw causal conclusions and to generalize the results respectively, we propose that our findings can still suggest avenues for schools and districts to consider when they think about ways to engage parents. Hence, having recognized the limitations of our study, we offer the following recommendations:

\section{Recommendations for practice}

1. Schools would benefit from designing and carrying out periodic cultural or "climate" assessments of their communities. These assessments should include not only demographic and other technical information, but also qualitative information about the perceptions and experiences of parents, students, teachers, administrators and other stakeholders. The findings of these assessments, once carefully interpreted, should be used along with other relevant data to create a school's Strategic Plan that actively and systematically validates alternative forms of parent involvement. As stated above, a thorough analysis of the nature and function of the alternative forms of capital manifested by EL communities will not only provide teachers, administrators, and policy makers with valuable information and tools they can use to create culturally-sustaining programs 
and schools, but also has the potential to counteract the negative effects of anti-immigrant policies and to create more equitable school environments.

2. In order to increase and improve parent involvement, a school's Strategic Plan should include a systematic, goal-oriented, measurable framework that includes meaningful opportunities for involvement (e.g., family counseling, adult education programs, and more power in decision-making processes) and the following:

- A strategic plan that identifies and addresses cultural nuances present in the community (i.e., gender dynamics, cultural differences within larger groups, community and social affiliations, etc.)

- A strategic plan that addresses the specific needs of newcomer families, particularly immigrants. Systematic structures of support must be created for immigrant parents to help them overcome barriers such as legal status, limited English skills, overemployment, and poor health; that play a major role in preventing their effective social integration or acculturation. This program should focus, among other things, on providing participants with the cultural capital—namely linguistic competence and knowledge of cultural and social structures - they need to navigate their new social ecosystem.

- The deliberate creation of contexts and designation of spaces in which parents can support and work with each other. This is particularly necessary to combat the effects of concentrated poverty and to help parents develop social support networks that can help them in the process of navigating their social ecosystem and engaging in their children's schooling. 
3. Administrators need to be visible and accessible. Accessibility should be regular and equitable: principals and other administrators must be available for all parents, and not just for those who are part of committees and/or associations.

\section{Recommendations for further research}

In further investigating the factors that influence parents' decisions to become involved at their children's schools, and considering our experience with fathers who declined participation in this study because they believe school-related matters are better left to their wives, it would be helpful to carry out research that focuses on answering questions about how Latinx fathers perceive their role in their children's education and how these perceptions are formed. It would also be important to investigate how fathers' perceptions affect their willingness to become involved at their children's schools and, most importantly, how their relative limited involvement affects their children's academic performance and overall development.

Also, as a result of our observation of parents who, despite their undocumented status, remain resilient and engaged in their children's schools, it would be relevant to study the effects of peer support. Given that parents in our study often credited other parents for their increased confidence and self-efficacy, learning more about the nature of interactions between parents could provide educators with additional knowledge and tools to create stronger community networks.

Lastly, as the U.S. continues to implement anti-immigrant policies that directly affect schools, it becomes imperative that research by both academics and practitioners on the effects of such policies become ongoing. 


\section{Closing Thoughts}

While we cannot make the claim that the schools and community leaders in our study are totally effective in addressing the needs of immigrant families, we will say-based on evidence and with some reservations - that key leaders at both PUSD and the Pomona City Council seem to understand the premise that parental involvement is not limited to an individual and his or her participation in an event, but rather that it also includes situations, contexts, and relationships. By making serious efforts to get to know the cultures of their Latinx immigrant constituents and by creating spaces where these families feel respected and safe, the leadership of Pomona has taken significant initial steps toward strengthening already-existent community bonds, and thus, the creation of a culture of trust where Latinx immigrant parents, regardless of legal status and in spite of adversarial policies, are willing to become involved at their children's schools. 


\section{References}

Abedi, J. \& Dietel, R. (2004). Challenges in the No Child Left Behind Act for English Language

Learners. National Center for Research on Evaluation, Standards, and Student Testing. Arellano, A. \& Padilla, A. (1996). Academic Invulnerability Among a Select Group of Latino University Students. Stanford University.

Arias, B. \& Morillo-Campbell, M. (2008). Promoting ELL Parental Involvement: Challenges in Contested Times. Education and the Public Interest Center. School of Education, University of Colorado. Boulder, CO.

Ascher, C. (1988). Improving the school-home connection for poor and minority urban students. Urban Review, 20(2), 109-123.

Auerbach, C. \& Silverstein, L. (2003). Qualitative data: An introduction to coding and analysis. New York: New York University Press.

Barnard, W. M. (2004). Parent involvement in elementary school and educational attainment. Children and Youth Services Review, 26, 39-62.

Bourdieu, Pierre. (1986). The Forms of Capital. Handbook of Theory and Research for the Sociology of Education. (pp. 241-258). New York: Greenwood Press.

Bryman, A. (2012), Social Research Methods, 4th ed, Oxford University Press, New York.

Calabrese Barton, A., Drake, C., Perez J.G., St. Louis, K. \& George, M. (2004). Ecologies of Parental Engagement in Urban Education. Educational Researcher, Vol. 33, No. 4, pp. 312.

Callahan, R. (2003). Opportunity to learn English in a California High School: Tracking and secondary English Learners Unpublished dissertation, University of California, Davis. 
Capps, R., Fix, M., Murray, J., Ost, J., Passel, J., \& Herwantoro, S. (2010). The New Demography of America's Schools: Immigration and the No Child Left Behind Act. The Urban Institute, Washington DC.

Carger, C.L. (1997). Attending to new voices. Educational Leadership, 54(7), 39-43

Comer, J. P. (1984). Home-school relationships as they affect the academic success of children. Education and Urban Society, 16(3), 323-337.

Comer, J. P. (2001). Schools that develop children. The American Prospect, 12(7), 3-12.

Cooper, H. (Ed.). (1989). Homework. New York: Longman.

Cooper, H. (2001). Homework for all—in moderation. Educational Leadership, 58, 34 -38.

Cooper, H., Jackson, K., Nye, B., \& Lindsay, J. J. (2001). A model of homework's influence on the performance of elementary school students. Journal of Experimental Education, 69, 181.

Cooper, H., Lindsey, J., \& Nye, B. (2000). Homework in the home: How student, family, and parenting-style differences relate to the homework process. Contemporary Educational Psychology, 25, 464-487.

Creswell, J. W. (1998). Quality inquiry and research design: Choosing among five traditions. Thousand Oaks.

Creswell, J. W., Hanson, W. E., Clark Plano, V. L., \& Morales, A. (2007). Qualitative research designs: Selection and implementation. The counseling psychologist, 35(2), 236-264.

Creswell, J. W. (2012). Education research: Planning, conducting, and evaluating quantitative and qualitative research (4th ed.). Boston: Pearson.

Crotty, M. (1998). The foundations of social research: Meaning and perspective in the research process. Sage. 
Crozier, G. (2001). Excluded Parents: The deracialisation of parental involvement [1], Race Ethnicity and Education, 4:4, 329-341, DOI: 10.1080/13613320120096643

Darling-Hammond, L. (2002). Access to quality teaching: An analysis of inequality in California' public schools. Expert report prepared for Williams v. State of California. Retrieved March 8, 2003 from http://www.mofo.com/decentschools/expertreports/darlinghammondreport.pdf.

De Carvalho, M.E., (2001). Rethinking Family-School Relations: A Critique of Parental Involvement in Schooling. Lawrence Erlbaum Associates, Publishers. Mahwah, New Jersey.

De Civita, M., Pagani, L., Vitaro, F., \& Tremblay, R. E. (2004). The role of maternal educational aspirations in mediating the risk of income source on academic failure in children from persistently poor families. Children and Youth Services Review, 26, 749-769.

De Gaetano, Y. (2007) The Role of Culture in Engaging Latino Parents' Involvement in School. Urban Education, Vol.42, No. 2. Pp. 145-162. Corwin Press.

Delgado-Gaitán, C. (1990). Literacy for empowerment: The role of parents in children's education. London: Falmer Press.

Delgado-Gaitan, C. (1991). Involving parents in schools: A process of empowerment. American Journal of Education 100(1):20-46.

Delgado-Gaitan, C. (2001). The power of community: Mobilizing for family and schooling. Lanham, MD: Rowman \& Littlefield Publishers.

Delpit, L. D. (1988). The silenced dialogue: Power and pedagogy in educating other people's children. Harvard Educational Review, 58, 280-298. 
Desimone, L. (1999). Linking parent involvement with student achievement: Do race and income matter? Journal of Educational Research, 93, 11-30.

Dumont, H., Trautwein, U., Lüdtke, O., Neumann, M., Niggli, A., \& Schnyder, I. (2012). Does parental homework involvement mediate the relationship between family background and educational outcomes? Contemporary Educational Psychology, 37, 55

Duncan, B. \& Trejo, S. (2018). Socioeconomic Integration of U.S. Immigrant Groups over the Long Term: The Second Generation and Beyond. NBER Working Paper No. 24394. Issued in March 2018. National Bureau of Economic Research.

Eamon, M. K. (2002). Effects of poverty on mathematics and reading achievement of young adolescents. Journal of Early Adolescence, 22, 49-74.

Epstein, J.L. (1995). School family/community partnerships: Caring for the children we share. Phi. Delta Kappan, 76, 701-712.

Epstein, J. L. (2001). School, family and community partnerships: Preparing educators and improving schools. Boulder, CO: Westview Press.

Epstein, J.L \& Dauber, S. (1991). School Programs and Teacher Practices of Parent Involvement in Inner-City Elementary and Middle Schools. The Elementary School Journal, Vol. 91, No. 3. Special Issue: Educational Partnerships: Home-School Community (Jan., 1991), pp. 289-305. University of Chicago Press.

Fan, X. T., \& Chen, M. (2001). Parental involvement and students' academic achievement: A meta-analysis. Educational Psychology Review, 13, 1-22.

Feuerstein, A. (2000). School characteristics and parent involvement: Influences on participation in children's schools. Journal of Educational Research, 94, 29-39. 
Ferguson, C. (2008). The School-Family Connection: Looking at the Larger Picture. National Center for Family and Community Connections in Schools. Austin, TX.

Finders, M., \& Lewis, C. (1994). Why some parents don’t come to school. Educational Leadership, 51(8), 50-54.

Fine, M. (1993). Parent involvement: Reflections on parents, power, and urban public schools. Teachers College Record, 94(4), 682-710.

Fix, M. \& Passel, J. (2003). U.S. Immigration—Trends \& Implications for Schools. National Association for Bilingual Education. NCLB Implementation Institute. New Orleans, LA.

Floyd, L. (1998). Joining hands: A parental involvement program. Urban Education, 33(1), 123135.

Freire, P. (2002). Pedagogy of the oppressed. 30th Anniversary Edition. New York: Continuum International.

Fuligni, A. (2001). A comparative longitudinal approach to acculturation among children from immigrant families. Harvard Educational Review, 71, 566-576.

Galster, G. (2010). "The Mechanism(s) of Neighborhood Effects: Theory, Evidence, and Policy Implications.” Presentation at the ESRC Seminar, St. Andrews University, Scotland, UK, 4-5 February 2010.

Gándara, P., Rumberger, R., Maxwell-Jolly, J., \& Callahan, R. (2003). English Learners in California Schools: Unequal resources, unequal outcomes. Education Policy Analysis Archives, 11(36). Retrieved from http://epaa.asu.edu/epaa/v11n36/.

Gándara, P. \& Ee, J. (2018). U.S. Immigration Enforcement and Policy and Its impact on Teaching and Learning in the Nation's Schools. Civil Rights Project, UCLA. 
Gibson, M.A. (2002). The new Latino diaspora and educational policy. In S. Wortham, E.G. Murillo, \& E.T. Hamann (Eds.), Education in the new Latino diaspora: Policy and the politics of identity. Westport, CT: Ablex Publishing

Gonzalez-DeHass, A.R., Willems, P., \& Doan, M. (2005). Examining the Relationship Between Parental Involvement and Student Motivation. Educational Psychology Review, Vol. 17, No 2 (2005), pp. 99-123.

Gonzalez-Mena, J. (1994). From a parent's perspective. Salem, WI: Sheffield.

Good, M.E., Masewicz, S., \& Vogel, L. (2010). Latino English Language Learners: Bridging Achievement and Cultural Gaps Between Schools and Families. Journal of Latinos and Education, 9:4, 321-339, DOI: $\underline{10.1080 / 153484431.2010 .491048}$

Green, G. \& Haines, A. (2012). Asset Building and Community Development. Sage Publications, Inc. Thousand Oaks, CA.

Greenwood, G. E., and Hickman, C. W. (1991). Research and practice in parent involvement: Implications for teacher education. Element. School J. 91(3):279-288.

Gutiérrez, K. D., Baquedano-López, P., \& Tejeda, C. (1999). Rethinking diversity: Hybridity and hybrid language practices in the third space. Mind, culture, and activity, 6(4), 286-303.

Gutman, L. M., \& McLoyd, V. C. (2000). Parents' management of their children's education within the home, at school, and in the community: An examination of African-American families living in poverty. The Urban Review, 32(1), 1-24.

Heath, S. B. (1983). Ways with words. New York, NY: Cambridge University Press.

Henderson, A. T., and Berla, N. (1994). A New Generation of Evidence: The Family is Critical to Student Achievement, National Committee for Citizens in Education, Columbia, MD. 
Hernandez, D.L., Denton, N.A., \& Macartney, S.E. (2008). Children in immigrant families: looking to America's future. Social Policy Report, 22, 3-22.

Hill, N. E., Castellino, D. R., Lansford, J. E., Nowlin, P., Dodge, K. A., Bates, J. E., et al. (2004). Parent academic involvement as related to school behavior, achievement, and aspirations: Demographic variations across adolescence. Child Development, 75, 1491-1509.

Hill, N. E., \& Tyson, D. F. (2009). Parental involvement in middle school: a meta-analytic assessment of the strategies that promote achievement. Developmental Psychology, 45(3), 740-763.

Hoover-Dempsey, K. V. \& Sandler, H. M. (1997). Why do parents become involved in their children's education? Review of educational research, 1997, 67, 3-42.

Jeynes, W. H. 2003. “A Meta-analysis of the Effects of Parental Involvement on Minority Children's Academic Achievement.” Education and Urban Society 35 (2): 202-218.

Kaptelinin, V. \& Nardi, B.A. (2006). Acting with Technology: Activity Theory and Interaction Design. MIT Press. ISBN 978-0262513319.

Kteily, N. \& Breneau, E. (2017) Backlash: The Politics and Real-World Consequences of Minority Group Dehumanization. Personality and Social Psychology Bulletin 2017. Vol. 43 (1) $87-104$.

Landale, M., \& Oropesa, R. (1995). Immigrant children and the children of immigrants: Inter and intra ethnic group differences in the U.S. East Lansing, MI: Institute for Policy and Social Research.

Lareau, A. \& Horvat, E.M. (1999). Moments of social inclusion and exclusion: Race, class, and cultural capital in family-school relationships. Sociology of Education, 72, 37-53. 
Lee, C. D. (2007). Culture, literacy, and learning: Taking bloom in the midst of the whirlwind. New York, NY: Teachers College Press.

Lee \& Bowen (2006) Parent Involvement, Cultural Capital, and the Achievement Gap Among Elementary School Children. American Educational Research Journal. Summer 2006, Vol. 43, No. 2, pp. 193-218.

Marshall, C., \& Gerstl-Pepin, C. I. (2005). Re-framing educational politics for social justice. Boston, MA: Pearson/Allyn and Bacon.

McQuiggan, M. and Megra, M. (2017). Parent and Family Involvement in Education: Results from the National Household Education Surveys Program of 2016 (NCES 2017-102).

U.S. Department of Education. Washington, DC: National Center for Education Statistics. Retrieved [date] from http://nces.ed.gov/pubsearch/pubsinfo.asp?pubid=2017102.

McWayne, C., Hampton, V., Fantuzzo, J., Cohen, H. L., \& Sekino, Y. (2004). A multivariate examination of parent involvement and the social and academic competencies of urban kindergarten children. Psychology in the Schools, 41, 363-377.

Meyers, B., Dowdy, J., \& Paterson, P. (2000). Finding the missing voices: Perspectives of the least visible families and their willingness and capacity for school involvement. Current Issues in Middle Level Education, 7(2), 59-79.

Miller, G. \& Kildee, D. (2007). Impact of No Child Left Behind on English Language Learners. HEARING BEFORE THE SUBCOMMITTEE ON EARLY CHILDHOOD, ELEMENTARY AND SECONDARY EDUCARION COMMITTEE ON EDUCATION AND LABOR. U.S. House of Representatives, One Hundred Tenth Congress, First Session. Washington, D.C., March 23, 2007. 
Moles, O.C. (1993). Collaboration between schools and disadvantaged parents: obstacles and openings. In N.F. Chavkin (Ed.), Families and schools in a pluralistic society. New York: State University of New York Press.

Morales, M.I. (2014). A City in Transition: Changing Demographics in Pomona, California 1980-2000. Unpublished study, Claremont Graduate University.

Nuñez, J.C., Suárez, N., Rosário, P., Vallejo, G., Valle, A., \& Epstein, J.L. (2015) Relationships between perceived parental involvement in homework, student homework behaviors, and academic achievement: differences among elementary, junior high, and high school students. Springer Science+Business Media, New York 2015.

O’Connor, S. (2001). Voices of parents and teachers in a poor white urban school. Journal of Students Placed at Risk, 6(3), 175-198.

Panferov, S. (2010). Increasing ELL Parental Involvement in Our Schools: Learning from the Parents. Theory into Practice, 49:2, 106-112, DOI: $\underline{10.1080 / 00405841003626551}$

Paris, D. (2012). Culturally Sustaining Pedagogy: A Needed Change in Stance, Terminology, and Practice. Educational Researcher 2012 41:93 DOI: 10.3102/0013189X12441244

Paris, D., \& Ball, A. (2009). Teacher knowledge in culturally and linguistically complex classrooms: Lessons from the golden age and beyond. In L. M. Morrow, R. Rueda, \& D. Lapp (Eds.), Handbook of research on literacy instruction: Issues of diversity, policy, and equity (pp. 379-395). New York, NY: Guilford.

Patall, E. A., Cooper, H., \& Robinson, J.C. (2008). Parent involvement in homework: A research synthesis. Review of Educational Research, 78, 1039-1101. doi $10.3102 / 0034654308325185$ 
Patton, M. Q. (2002). Two decades of developments in qualitative inquiry: A personal, experiential perspective. Qualitative social work, 1(3), 261-283.

Pérez Carreón, G., Drake, C., \& Calabrese Barton, A. (2005). The Importance of Presence: Immigrant Parents' School Engagement Experiences. American Educational Research Journal. Fall 2005, Vol. 42, No. 3, pp. 465-498.

Perez, L. (2016) Make America Great again: Donald Trump, Racist Nativism and the Virulent Adherence to White Supremacy Amid U.S. Demographic Change. 10 Charleston L. Rev. 215.

Pomerantz, E. M., \& Eaton, M. M. (2001). Maternal intrusive support in the academic context: transactional socialization processes. Developmental Psychology, 37, 174-186.

Portes, A., \& Rumbaut, R. G. (2001). Legacies: The Story of the Immigrant Second Generation. Berkeley, CA: University of California Press.

Ramirez, A.Y. Fred (2003). Dismay and Disappointment: Parental Involvement of Latino Immigrant Parents. The Urban Review, Vol. 35, No. 2.

Roth, W. (2004). Activity Theory and Education: An Introduction. Mind, Culture, and Activity. 11. MIND, CULTURE AND ACTIVITY, II (1), 1-8.

Roth, W. \& Lee, Y. (2007). "Vygotsky's Neglected Legacy": Cultural-Historical Activity Theory. Review of Educational Research Vol 77 Issue 2. pp. 186-232.

Ruiz-de-Velasco, Jorge, and Michael Fix, with Beatriz Chu Clewell. 2000. Overlooked and Underserved: Immigrant Students in U.S. Secondary Schools. Washington, DC: The Urban Institute.

Schreiber, J. B. (2002). Institutional and student factors and their influence on advanced mathematics achievement. Journal of Educational Research, 95, 274-286. 
Smitherman, G. (1977). Talkin and testifyin. Detroit: Wayne State University Press.

Souto-Manning, M. (2005b). Critical narrative analysis of Brazilian women's schooling discourses: Negotiating agency and identity through participation in Freirean culture circles. Athens: Unpublished doctoral dissertation, University of Georgia.

Souto-Manning \& Swick (2006). Teachers' Beliefs about Parent and Family Involvement: Rethinking our Family Involvement Paradigm. Early Childhood Education Journal, Vol.34, No. 2, October 2006. DOI: 10/1007/s10643-006-0063-5

Strauss, A. L. (1987). Qualitative analysis for social scientists. Cambridge University Press.

Suárez-Orozco, M., \& Suárez-Orozco, C. (2000). Some conceptual considerations in the interdisciplinary study of immigrant children. In E. Trueba \& L. Bartolome (Eds.), Immigrant voices: In search of educational equity. Lanham, MD: Rowman \& Littlefield.

Suarez-Orozco, C., Suarez-Orozco, M., Todorova, C. (2008). Learning a New Land: Immigrant students in American society. Cambridge: Harvard University Press.

Suárez-Orozco, C., Suárez-Orozco, M., Todorova, C. (2010). Learning a New Land: Immigrant Students in American Society. Cambridge: Harvard University Press.

Swick, K. (2004). Empowering parents, families, schools, and communities during the early childhood years. Champaign, IL: Stipes.

Tapia, J. (2000). Schooling and learning in U.S.-Mexican families: A case study of households. Urban Review, 32, 25-44.

Tarasawa, B. \& Waggoner, J. (2015). Increasing Parental Involvement of English Language Learner Families: What the Research Says. Journal of Children and Poverty. 2:12, 129134, DOI: $\underline{10.1080 / 10796126.2015 .1058243}$ 
Trueba, E. (1999). Latinos Unidos: From cultural diversity to the politics of solidarity. Lanham, MD: Rowman \& Littlefield.

Trueba, E. (2004). The new Americans: Immigrants and transnationals at work. Lanham, MD: Rowman \& Littlefield

Tushnet, M. (2002). Brown vs. Board of Education. In A. Gordon-Reed (Ed.), Race on trial, law and justice in American history (234 pp.). New York: Oxford University Press.

Valdés, G. (1996). Con respeto: Bridging the distances between culturally diverse families and schools. New York, NY: Teachers College Press.

Villanueva, I., \& Hubbard, L. (1994, April). Toward redefining parent involvement: Making parents' invisible strategies and cultural practices visible. Paper presented at the annual meeting of the American Educational Research Association, New Orleans.

Villenas, S., \& Dehyle, S. (1999). Race is . . race isn't. Boulder, CO: Westview.

Vygotsky, L.S. (1978). Mind in Society: the Development of Higher Psychological Processes. Cambridge, MA: Harvard University Press. ISBN 0-67457629-2.

Williams, D.L. \&Stallworth, J.T. (1984). Parent involvement in education: What a survey reveals. Austin, TX: Parent Involvement in Education Project, Southwest Regional Educational Development Laboratory. 


\section{Appendices}

Appendix A.

\section{PARTICIPATION REQUEST}

\section{Dear [NAME],}

I am an educator and fifth-year Ph.D. student in the Teaching, Learning, and Culture program in the School of Educational Studies at Claremont Graduate University in Claremont, CA. I am currently working on my dissertation which seeks to explore the experiences and perceptions of Latinx immigrant and/or English Language Learner parents and the ways in which these affect their ability and/or willingness to engage with their children's schools.

I would like to extend to you an invitation to participate in this study. Your voluntary participation would entail partaking in a one-hour interviews and a shorter 30- to 45minutes follow-up interview at a later date. You will have the opportunity to read and revise your interview transcription prior to the publication of the study.

Because this research is not funded, I am unable to offer compensation for your participation. However, this study will benefit learning communities by providing a deeper understanding of the underlying motivations for successful parent engagement.

The world needs to know and understand your perceptions and experiences. Your participation will be a major contribution to this study! If you would like more information, please feel free to email me at maria.morales@cgu.edu. Thank you for your time and serious consideration.

Sincerely,

Maria I. Morales 


\section{Appendix B.}

\section{CONSENT FORM}

STUDY LEADERSHIP. I am asking you to take part in a research project that is led by Maria Morales, Principal Investigator and doctoral candidate of Education at Claremont Graduate University. Please note that this study will be supervised by Dr. Lucrecia Santibañez, Associate Professor at Claremont Graduate University.

PURPOSE. The purpose of this study is to examine Latinx immigrant parent experiences and perceptions and the ways in which these affect their ability and/or willingness to engage with their children's schools.

ELIGIBILITY. To take part in this study, you must be a Latinx parent of a student currently enrolled as an English Language Learner in an elementary school in southern California.

PARTICIPATION. This study requires the researcher to conduct one-hour interviews with parents and a onehour interview with a school leader and another one-hour interview with a community leader. Additionally, a focus group meeting will be held with all participating parents.

RISKS OF PARTICIPATION. The risks you run by taking part in this study are minimal, and not higher than those faced in everyday life. The risk includes the possibility that you may occasionally feel uncomfortable with or dislike certain interview questions. You may opt out of the study at any time.

BENEFITS OF PARTICIPATION. The study will benefit policymakers, scholars, school administrators, and teachers by providing them with a deeper understanding of factors that influence parent's choices to become involved in their children's schools.

COMPENSATION: This study is completely voluntary; thus, your participation, though greatly valued, will not include any form of compensation.

VOLUNTARY PARTICIPATION. Because your participation in this study is completely voluntary, you may choose not to participate at all or withdraw from the study at any time. Also, you may refuse to answer any or all parts of a question for any reason without it being held against you. Your decision whether or not to participate will have no effect on your current or future connection with anyone at the Claremont Graduate University.

CONFIDENTIALITY: This study will use voice recording. The confidentiality of all voice recordings and non-public data is a priority. The data collected for the sole purpose of identifying said schools and voice recordings will be stored on a password-protected computer, in a secured, password-protected folder and will be destroyed within two years of the publication of the research as is the custom in academia. Data will only be shared with faculty members of the Claremont Colleges who comprise Maria's dissertation committee.

FURTHER INFORMATION. If you have any questions or would like additional information about this study, please contact Maria I. Morales at maria.morales@cgu.edu. The CGU Institutional Review Board has certified this project as 
exempt. You may contact the CGU Board with any questions or issues at (909) 607-9406 or at irb@cgu.edu. A copy of this form will be given to you if you wish to keep it.

CONSENT. By signing below you are giving your consent to the fact that you understand the information on this form, that any questions you may have about this study have been answered, and that you are eligible and voluntarily agree to participate.

Participant's signature:

Date:

Print name:

[If Applicable:] The undersigned researcher has reviewed the information in this consent form with the participant and answered any of his or her questions about the study.

Signature of Researcher Date

Printed Name of Researcher

***Please keep a copy of this consent form for your records*** 
Appendix C.

\section{DEMOGRAPHIC QUESTIONNAIRE}

\section{Mother/Father/Caregiver}

Name of Participant:

Telephone number:

Email Address:

Marital Status:
Single
Married
Widow/er
Other

Age:

20-30

$30-40$

$40-50$

$50+$

Country of origin:

Time lived in the United States:

Highest Educational Level attained:

Do you live in the immediate community of your child's school?

$$
\text { Yes no }
$$

How long have you lived at your current address?

If you do not reside in your child's immediate community, what is the reason? (Please use the back of this page for additional space) 
Residence:

Own Rent Other

Are you currently employed outside the home?

Yes No

If you are currently employed outside of the home, how many hours do you work per week?

What is household's monthly income?

$\$ 0-2,000$

$\$ 2001-3,000$

$\$ 3,001-4,000$

$\$ 4,001+$

\section{Student Information:}

\section{Student\#1}

Name of School

Grade level

Time attending this school

\section{Student\#2}

Name of School

Grade level

Time attending this school 


\section{Student\#3}

Name of School

Grade level

Time attending this school

(Please use the back of this page for additional space)

\section{OPTIONAL:}

Are you willing to share information about your legal status in the U.S? 


\section{Cuestionario de Información Demográfica}

(Demographic Information Questionnaire: Spanish Version)

\section{Madre/Padre/Tutor(a)}

Nombre del/a participante:

Número de teléfono:

Dirección de correo eléctronico:

Estado civil:

Soltera/o

Casada/o

Viuda/o

Otro

Edad:

$20-30$

$30-40$

$40-50$

$50+$

País de origen:

¿Cuanto tiempo tiene viviendo en los Estados Unidos?

Nivel Educativo alcanzado

¿Vive ud. en la comunidad immediata donde se encuentra la escuela de su hijo/a?

¿Cuanto tiempo tiene viviendo ahí? 
Si no vive en la comunidad immediata donde se encuentra la escuela de su hija/o, ¿cúal es la razón? (favor de utilizar el reverso de esta hoja si necesita mas espacio)

¿Condición de su residencia?

Propia

Renta

Otra

¿Está usted empleada/o fuera del hogar?

Sí

No

Si está empleada fuera del hogar, ¿̇cuantas horas trabaja por semana?

¿Cuales son los ingresos mensuales de su hogar?

$\$ 1,000-2,000$

$\$ 2,001-3,000$

$\$ 3,001-4,000$

$\$ 4,001+$

\section{Informacion del Estudiante(s):}

\#1

Escuela:

Grado escolar: 
Tiempo en esta escuela

\#2

Escuela:

Grado escolar:

Tiempo en esta escuela:

\#3

Escuela:

Grado escolar:

Tiempo en esta escuela:

*Favor de usar el reverso de esta hoja para incluir estudiantes adicionales

OPCIONAL*

Esta dispuesto/a a hablar sobre su estatus legal en los Estados Unidos? 
Appendix D.

\title{
INTERVIEW PROTOCOL FOR PARENTS
}

\author{
Parent Interview (Part 1) \\ Perceptions \& Experiences
}

Purpose of the study:

The purpose is to gauge Latinx immigrant/ELL parent experiences and perceptions and the ways in which these have affected their ability and/or willingness to engage with their children's schools since 2015 when anti-immigrant policies became more evident and hostile.

Questions:

1. As an immigrant, how do you feel about participating in school events? Do you feel the staff (including teachers, administrators, and other staff) at your child's school make efforts to help you feel welcome and comfortable? If so, can you give examples of these efforts? Do these efforts encourage you to ask questions and make suggestions regarding school matters? If not, what makes you feel that way?

2. Do you think it is important for the staff in your child's school to know and understand the culture of your family? If so, do you feel your child's school understands your family's culture? What makes you think that way? Do you feel your child's school staff understands and respects your ethnic and family culture? What makes you feel that way?

3. Can you name at least one person in your child's school that you can confidently approach to answer any questions you may have regarding your child's academic performance or any other school-related topics? If so, who is this person? What is her/his role in the school? How often and under what circumstances do you interact with this person? What makes you feel comfortable approaching this person?

4. As an immigrant, how do you feel about participating in community events? What makes it so?

5. Do you feel your community is a space where you and other immigrants are encouraged to voice your opinions? What makes it so?

6. Do you think it is important for your community's leaders (i.e., Mayor, council members, school superintendent, etc.) to know and understand the culture of your family and those of other immigrants? If so, do you feel your community's leaders understand your 
family's culture? What makes you think that way? Do you feel your community's leaders understand and respect your ethnic and family culture? What makes you feel that way?

7. Can you name at least one community leader that you can confidently approach to share your thoughts on community-related or any other issues that affect you and your family? If so, who is this person? What is his/her role in the community? How often and under what circumstances do you interact with this person? What makes you feel comfortable approaching this person?

8. Do you perceive any differences between state and federal immigration policies? If so, what are these differences and how do they affect you and your family?

9. Have the changes in immigration policies in the last three years affected your perception of your child's school? If so, how have these changes affected your willingness to become more involved in your child's school?

10. Would you like to add anything? 


\section{Parent Interview (Part 1)}

\section{SPANISH VERSION}

Proposito del estudio:

El proposito de este estudio es analizar las experiencias y percepciones de madres/padres immigrantes Latinxs y la manera en que estas han afectado su disposicion y habilidades para involucrarce en las actividades de las escuelas de sus hijos/as desde el año 2015 cuando las leyes anti-immigrantes se hicieron mas evidentes y hostiles.

Preguntas:

1. Como miembro de la comunidad immigrante, ¿cómo se siente usted al participar en eventos escolares? ¿Siente ud. que el personal de la escuela de su hijo/a hace un esfuerzo por hacerle sentir bienvenido/a y comoda/o? De ser asi, ¿podria dar ejemplos de estos esfuerzos? A raiz de estos esfuerzos, ¿se siente ud. comoda/o para hacer preguntas o sugerencias sobre asuntos relacionados a la education de su hijo/a o de la escuela en general? De no ser asi, ¿que le hace sentir asi?

2. ¿Cree que es importante que el personal de la escuela de su hijo/a conozca y comprenda la cultura de su familia? De ser asi, ¿cree ud. que ellos/as conocen, comprenden y respetan su cultura? ¿Que le hace creer esto?

3. ¿Puede nombrar por lo menos una persona en la escuela de su hijo/a con la cual se siente ud. cómoda/o para hacer preguntas relacionadas al progreso académico de su hija/o o sobre cualquier otro tema relacionado a la escuela? De ser asi, ¿quien es esa persona? ¿Cuál es su posición en la escuela? ¿Que hace que ud. se sienta cómoda con esta persona?

4. ¿Como miembro de la comunidad inmigrante, como se siente al participar en eventos comunitarios? ¿Que hace que se sienta asi?

5. ¿Siente que su comunidad es un espacio donde ud. y otros/as inmigrantes pueden expresar sus opiniones sin preocupaciones? ¿Que le hace pensar asi?

6. ¿Cree ud. que es importante que los/as líderes de su comunidad conozcan y comprendan la cultura de su familia y la de otras familias imigrantes? De ser asi, ¿siente que las/os líderes de su comunidad conocen y respetan su cultura? ¿Que le hace pensar asi? 
7. ¿Puede nombrar por lo menos un/a líder comunitario/a con la cual se siente ud. cómoda/o para hacer preguntas o comentarios sobre asuntos comunitarios que afectan a su familia? De ser asi, ¿quien es esa persona? ¿Cuál es su posición en la comunidad? ¿Que tan seguido y bajo qué circunstancias convive con esta persona? ¿Que hace que ud. se sienta cómoda con esta persona?

8. ¿Percibe ud. diferencias entre las leyes de inmigración estatales y federales? De ser asi, ¿cuales son y como afectan a su familia?

9. ¿Se ha visto afectada su participacion en la escuela de sus hijas/os debido a los cambios en las leyes migratorias de los ultimos tres años? ¿De ser asi, como?

10. ¿Le gustaria añadir algo más? 


\section{Parent Interview (Part 2)}

Determining Factors in Involvement

1. How would you define "parental involvement"?

2. Do you involve yourself in your child's education? If so, how?

3. When was the last time you visited your child's school? What was the reason for the visit?

4. On average, how many times during the semester do you visit your child's school and with what purpose?

5. Has your participation in school activities changed in the last three years? If so, how? What prompted the changes?

6. Do you participate in public community events (i.e., town hall meetings, school board meetings, musical events, etc.)? If so, when was the last time you attended a community event?

7. Has your participation in community events changed in the last three years? If so, how? What prompted the changes?

8. Would you like to add anything? 


\section{Parent Interview (Part 2) \\ SPANISH VERSION}

\section{Determining Factors in Parent Involvement}

1. ¿Como define la involucración de los padres/madres en la educación de sus hijas/os?

2. ¿Se involucra ud. en la educación de su hija/o? como?

3. ¿Cuando fué la última vez que visito la escuela de su hijo/a? ¿Cuál fue la razón de la visita?

4. ¿En promedio, cuantas veces al semestre visita la escuela de su hijo/a? ¿Con que proposito?

5. ¿Ha cambiado su participación en actividades escolares en los últimos tres años? De ser así, como? ¿Cuál es la causa de estos cambios?

6. ¿Participa ud. en eventos comunitarios (reuniones del concilio de la ciudad, reuniones de la mesa directiva escolar, eventos musicales, etc.)? ¿De ser así, cuando fué la última vez que asistio a uno de estos eventos?

7. ¿Ha cambiado su participación en eventos comunitarios en los últimos tres años? De ser asi, cómo? Cuál es la causa de estos cambios?

8. ¿Le gustaria añadir algo mas? 
Appendix E.

\section{INTERVIEW PROTOCOL FOR SCHOOL \& COMMUNITY LEADERS}

\section{School Leader Interview}

Parent involvement

1. How do you define parent involvement? Is this a school-wide instituted definition?

2. In your view, what are some necessary components of successful parent involvement?

3. How would you describe parent involvement in your school?

4. Have you noticed changes in parent involvement patterns in the last three years? If so, what has caused these changes?

School culture

1. How do you describe the constituency of your school?

2. Do you believe your school has a "culture"? If so, how would you describe it?

3. Would you say parents and/or other community stakeholders share your perception of the school's culture?

4. Would you like to add anything?

\section{Community Leader Interview}

Community engagement

1. How do you define community engagement?

2. In your view, what are some components of successful community engagement?

3. How would you describe the engagement of residents in your community?

4. Have you noticed changes in community engagement patterns in the last three years? If so, what do you believe has caused these changes?

Community Culture

1. How do you describe the constituency of your community?

2. Do you believe your community has a "culture"? If so, how would you describe it?

3. Would you say community members share your perception of the community's culture?

4. Would you like to add anything? 
Appendix F.

\section{IRB APPROVAL}

\section{(4) Claremont Graduate University Institutional Review Board}

Dear Maria,

Thank you for submitting your research protocol to the IRB at Claremont Graduate University for review. On 08/31/2018, based on the information provided for Protocol \#3197, we have certified it as exempt from IRB supervision under CGU policy and federal regulations at 45 CFR 46.101(b)(2).

Exempt status means that so long as the study does not vary significantly from the description you have given us, further review in the form of filing annual Renewal or project Closure forms is not necessary. You may specify in relevant study documents, such as consent forms, that CGU human subjects protection staff members have reviewed the study and determined it to be exempt from IRB supervision. The IRB does not "approve" (or disapprove) studies that are exempt, so kindly avoid use of this verb.

Please note carefully that maintaining exempt status requires that (a) the risks of the study remain minimal, that is, as described in the application; (b) that anonymity or confidentiality of participants, or protection of participants against any higher level of risk due to the internal knowledge or disclosure of identity by the researcher, is maintained as described in the application; (c) that no deception is introduced, such as reducing the accuracy or specificity of information about the research protocol that is given to prospective participants; (d) the research purpose, sponsor, and recruited study population remain as described; and (e) the principal investigator $(\mathrm{PI})$ continues and is not replaced.

Changes in any such features of the study as described may affect one or more of the conditions of exemption and would very likely warrant a reclassification of the research protocol from exempt status and require additional IRB review. If any such changes are contemplated, please notify the IRB as soon as possible and before the study is begun or changes are implemented. If any events occur during the course of research, such as unexpected adverse consequences to participants, that call into question the features that permitted a determination of exempt status, you must notify the IRB as soon as possible.

Please note that a series of suggestions may also be attached to this email. These are suggestions to develop or improve your research protocol. These suggestions are highly recommended but not required. You do not need to send anything back to the IRB.

If Applicable: Most listservs, websites, and bulletin boards have policies regulating the types of advertisements or solicitations that may be posted, including from whom prior approval must be obtained. Many institutions and even classroom instructors have policies regarding who can solicit potential research participants from among their students, employees, etc., what information must be included in solicitations, and how recruitment notices are distributed or posted. You should familiarize yourself with the policies and approval procedures required of you to recruit for or conduct your study by listservs, websites, institutions, and/or instructors. Approval or exemption by the CGU IRB does not substitute for these approvals or release you from assuring that you have gained appropriate approvals before advertising or conducting your study in such venues.

The IRB may be reached at (909) 607-9406 or via email to irb@cgu.edu. KGI personnel with questions about their exempt status should contact KGI's Office of Research and Sponsored Projects at (909) 607-9313 or irb@kgi.edu. The IRB wishes you well in the conduct of your research project.

Sincerely,

Andrew Conway, James Griffith

IRB Chair IRB Manager

andrew.conway@cgu.edu_james.griffith2@cgu.edu 